\title{
Novel Tetradentate Phosphonate Ligand Based Bioinspired Co- Metal-Organic Frameworks: Robust Electrocatalyst for the Hydrogen Evolution Reaction in Different Mediums
}

Debabrata Chakraborty, ${ }^{\dagger, a}$ Avik Chowdhury, ${ }^{\dagger, a}$ Moumita Chandra, ${ }^{\S, b}$ Rajkumar Jana, ${ }^{\S, c}$ Sanjib Shyamal, ${ }^{\mathrm{a}}$ Manas K Bhunia, ${ }^{\mathrm{d}}$ Debraj Chandra, ${ }^{\mathrm{d}}$ Michikazu Hara, ${ }^{\mathrm{e}}$ Debabrata Pradhan, ${ }^{\mathrm{b}}$ Ayan Datta, ${ }^{\mathrm{c}}$ Asim Bhaumik ${ }^{\mathrm{a} *}$

${ }^{a}$ School of Materials Sciences, Indian Association for the Cultivation of Science, $2 A \& 2 B$

Raja S. C. Mullick Road, Jadavpur, Kolkata - 700032, India.

${ }^{b}$ Materials Science Center, Indian Institute of Technology Kharagpur, Kharagpur 721302, India.

${ }^{c}$ School of Chemical Sciences, Indian Association for the Cultivation of Science, Jadavpur, 700 032, India.

${ }^{d}$ World Research Hub Initiative (WRHI), Institute of Innovative Research, Tokyo Institute of Technology, Nagatsuta-cho 4259, Midori-ku, Yokohama 226-8503, Japan.

${ }^{e}$ Laboratory for Materials and Stuctures, Institute of Innovative Research, Tokyo Institute of Technology,Nagatsuta-cho 4259, Midori-ku, Yokohama 226-8503, Japan.

\section{Supporting information}

\begin{tabular}{|l|l|c|}
\hline Entry & \multicolumn{1}{|c|}{ Table of Contents } & Page No. \\
\hline Table S1 & $\begin{array}{l}\text { Bond distance and bond angles obtained from the CIF file of the } \\
\mathrm{H}_{8} \mathrm{~L}-\text { Co-Crystal. }\end{array}$ & S4 \\
\hline Table S2 & $\begin{array}{l}\text { Unit cell parameters from the PXRD analysis of } \mathrm{H}_{8} \mathrm{~L}-\mathrm{Co}-\mathrm{Crystal} \\
\text { for the sample suspended in different dry organic solvents. }\end{array}$ & S5 \\
\hline Fig. S1 & ORTEP model of the asymmetric unit of $\mathrm{H}_{8} \mathrm{~L}-$ Co-Crystal. & S6 \\
\hline Fig. S2 & $\begin{array}{l}\text { The phosphonate based } \mathrm{H}_{8} \mathrm{~L} \text { ligand structure (a) and 3D network } \\
\text { of the Co-MOF (b). }\end{array}$ & S7 \\
\hline Fig. S3 & PXRD of $\mathrm{H}_{8} \mathrm{~L}-\mathrm{Co}-$ Crystal: a: simulated, b: as-synthesized. \\
\hline
\end{tabular}




\begin{tabular}{|c|c|c|}
\hline Fig. S4 & $\begin{array}{l}\text { PXRD pattern of } \mathrm{H}_{8} \mathrm{~L}-\mathrm{Co}-\mathrm{crystal} \text { synthesized at different } \mathrm{pHs} \text { : a: } \\
\text { simulated, b: } \mathrm{pH}=1.0, \mathrm{c} ; \mathrm{pH}=3.0, \mathrm{~d}: \mathrm{pH}=4.0, \mathrm{e}: \mathrm{pH}=7.0 \text {, f: } \\
\mathrm{pH}=9.0 .\end{array}$ & S9 \\
\hline Fig. S5 & $\begin{array}{l}\text { Comparative PXRD data of } \mathrm{H}_{8} \mathrm{~L}-\mathrm{Co} \text {-crystal in different solvents } \\
\text { for } 60 \text { days: a: simulated, b: as synthesized, solvent exchanged } \\
\text { with benzene (c), hexane (d), acetonitrile (e) and methanol (f). }\end{array}$ & $\mathbf{S 1 0}$ \\
\hline Fig. S6 & $\begin{array}{l}\text { Stability of } \mathrm{H}_{8} \mathrm{~L}-\mathrm{Co}-\mathrm{crystal} \text { in different solvent mixtures for } 60 \\
\text { days, a: simulated, b: water, c: water+MeOH, d: } \mathrm{MeOH}+\mathrm{MeCN} \text {. }\end{array}$ & S11 \\
\hline Fig. S7 & In-situ temperature dependent PXRD. & S12 \\
\hline Fig. S8 & $\mathrm{N}_{2}$ sorption isotherm at $77 \mathrm{~K}$ of $\mathrm{H}_{8} \mathrm{~L}-\mathrm{Co}-\mathrm{Crystal}$. & S13 \\
\hline Fig. S9 & $\begin{array}{l}\text { UV-Vis DRS spectra of suspended } \mathrm{H}_{8} \mathrm{~L}-\mathrm{Co}-\mathrm{Crystal} \text { in different } \\
\text { polar and non-polar solvents: a: } \mathrm{H}_{8} \mathrm{~L}, \mathrm{~b} \text { : } \mathrm{H}_{8} \mathrm{~L}-\mathrm{Co}-\mathrm{Crystal} \text {, c: } \\
\text { methanol, d: acetonitrile, e: benzene, f: hexane. }\end{array}$ & S14 \\
\hline Fig. S10 & The band gap calculation of $\mathrm{H}_{8} \mathrm{~L}-\mathrm{Co}-\mathrm{Crystal}$ using Tauc-Plot. & S15 \\
\hline Fig. S11 & FT-IR spectra of $\mathrm{H}_{8} \mathrm{~L}$ (a) and $\mathrm{H}_{8} \mathrm{~L}-\mathrm{Co}-$ Crystal (b) & S16 \\
\hline Fig. S12 & 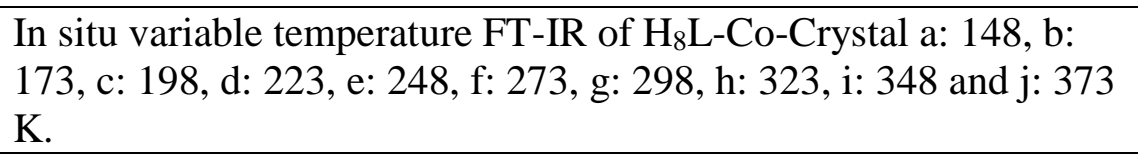 & S17 \\
\hline Fig. S13 & Full view XPS spectrum of As synthesized Co-H8L crystal & S18 \\
\hline Fig. S14 & $\begin{array}{l}\text { TG-DTA profiles of } \mathrm{H}_{8} \mathrm{~L}-\mathrm{Co}-\mathrm{Crystal} \text { recorded under } \mathrm{N}_{2} \text { (a) and } \\
\text { air (b) atmosphere. }\end{array}$ & S19 \\
\hline Fig. S15 & $\begin{array}{l}\text { The rectangular block shaped crystal of the } \mathrm{H}_{8} \mathrm{~L}-\mathrm{Co}-\mathrm{Crystal} \text { from } \\
\text { different side of view with different magnification, a: front view } \\
\text { of the crystal, b: upper surface of the crystal. }\end{array}$ & S20 \\
\hline Fig. S16 & $\begin{array}{l}\text { The electrochemical impedance spectroscopy of } \mathrm{H}_{8} \mathrm{~L}-\mathrm{Co} \mathrm{MOF} \text { in } \\
\text { various electrolytic mediums }\end{array}$ & S21 \\
\hline Fig. S17 & $\begin{array}{l}\text { LSV plot before and after } 1000 \mathrm{CV} \text { cycles in (a) } \mathrm{pH}=4 \text {, (b) } \mathrm{pH}=6 \text {, } \\
\text { (c) sea water medium and (d) chrono-amperometry curve upto } 5 \\
\text { hours in } 0.5 \mathrm{M} \mathrm{H}_{2} \mathrm{SO}_{4} \text { medium using graphite electrode }\end{array}$ & S22 \\
\hline Fig. S18 & $\begin{array}{l}\text { Cyclic voltammograms obtained from the non-Faradic region of } \\
\mathrm{H}_{8} \mathrm{~L}-\mathrm{Co}-\text { Crystal MOF at different scan rates in different } \\
\text { electrolyte mediums. }\end{array}$ & S23 \\
\hline Fig. S19 & $\begin{array}{l}\text { Chrono-amperometry curve upto } 5 \mathrm{~h} \text { in } 0.5 \mathrm{M} \mathrm{H}_{2} \mathrm{SO}_{4} \text { medium, } \\
\text { and Cdl calculation of } \mathrm{H}_{8} \mathrm{~L}-\mathrm{Co}-\mathrm{Crystal} \mathrm{MOF} \text { in different } \\
\text { electyrolyte mediums. }\end{array}$ & S24 \\
\hline Fig. S20 & PXRD pattern of $\mathrm{H}_{8} \mathrm{~L}-\mathrm{Co}-\mathrm{Crystal}$ before and after catalytic cycle & $\mathbf{S 2 5}$ \\
\hline Fig. S21 & UV-vis spectrum of Co-H8L before and after catalysus & S26 \\
\hline Fig. S22 & Gas chromatography & S27 \\
\hline Fig. S23 & $\begin{array}{l}\text { Optimized structure of } \mathrm{H}^{*} \text { adsorbed (on A-site of Co) } \mathrm{H}_{8} \mathrm{~L}-\mathrm{Co}- \\
\text { Crystal (200) surface }\end{array}$ & S28 \\
\hline Fig. S24 & Charge density difference (CDD) plot (isodensity value at & S29 \\
\hline
\end{tabular}




\begin{tabular}{|c|c|c|}
\hline & $\begin{array}{l}\text { surfaces is } \pm 0.002 \text { e/au }{ }^{3} \text { (positive: cyan and negative: olive) of } \mathrm{H}^{*} \\
\text { adsorbed } \mathrm{H}_{8} \mathrm{~L}-\mathrm{Co}-\mathrm{Crystal}(200) \text { surface. }\end{array}$ & \\
\hline Fig. S25 & $\begin{array}{l}\text { Optimized structure of } \mathrm{H}_{8} \mathrm{~L}-\mathrm{Co}-\mathrm{Crystal}(200) \text { surface after second } \\
\mathrm{H}^{*} \text { adsorption on } \mathrm{H}^{*}-\mathrm{H}_{8} \mathrm{~L}-\mathrm{Co}-\mathrm{Crystal}(200) \text {. }\end{array}$ & S30 \\
\hline Experiments & $\begin{array}{l}\text { Synthetic procedure of } \mathrm{H}_{8} \mathrm{~L} \text { ligand starting from bezophenone with } \\
{ }^{1} \mathrm{H},{ }^{13} \mathrm{C} \text { and }{ }^{31} \mathrm{P} \text { NMR (Figures S26-32), crystal structure } \\
\text { determination technique and calculation of TOF in electrochemical } \\
\text { HER. }\end{array}$ & S31-S36 \\
\hline References & References & S37 \\
\hline
\end{tabular}


Table S1. Bond distance and bond angles obtained from CIF of $\mathrm{H}_{8} \mathrm{~L}-\mathrm{Co}-\mathrm{Crystal}$

\begin{tabular}{|l|l|l|l|}
\hline $\mathrm{Co}(1)-\mathrm{O}(\mathrm{B})$ & $2.165(\AA)$ & $\mathrm{O}(4)-\mathrm{Co}(1)-\mathrm{O}(4)$ & $81.91\left(^{\circ}\right)$ \\
\hline $\mathrm{Co}(1)-\mathrm{O}(\mathrm{C})$ & $2.094(\AA)$ & $\mathrm{P}(3)-\mathrm{O}(5)-\mathrm{Co}(1)$ & $135.66\left(^{\circ}\right)$ \\
\hline $\mathrm{Co}(1)-\mathrm{O}(4)$ & $2.145(\AA)$ & $\mathrm{Co}(1)-\mathrm{O}(4)-\mathrm{Co}(1)$ & $98.09\left(^{\circ}\right)$ \\
\hline $\mathrm{Co}(1)-\mathrm{O}(5)$ & $2.059(\AA)$ & $\mathrm{C}(\mathrm{J})-\mathrm{C}(1)-\mathrm{C}(\mathrm{O})$ & $119.47\left(^{\circ}\right)$ \\
\hline $\mathrm{Co}(1)-\mathrm{O}(6)$ & $2.085(\AA)$ & $\mathrm{C}(\mathrm{J})-\mathrm{C}(1)-\mathrm{C}(\mathrm{P})$ & $121.39\left(^{\circ}\right)$ \\
\hline $\mathrm{P}(3)-\mathrm{O}(5)$ & $1.513(\AA)$ & $\mathrm{P}(2)-\mathrm{C}(\mathrm{F})-\mathrm{C}(\mathrm{L})$ & $119.23\left(^{\circ}\right)$ \\
\hline $\mathrm{P}(3)-\mathrm{O}(8)$ & $1.557(\AA)$ & $\mathrm{P}(2)-\mathrm{C}(\mathrm{F})-\mathrm{C}(\mathrm{D})$ & $121.85\left(^{\circ}\right)$ \\
\hline $\mathrm{P}(3)-\mathrm{O}(9)$ & $1.501(\AA)$ & $\mathrm{C}(\mathrm{M})-\mathrm{C}(\mathrm{K})-\mathrm{C}(\mathrm{H})$ & $120.31\left(^{\circ}\right)$ \\
\hline $\mathrm{P}(2)-\mathrm{O}(\mathrm{A})$ & $1.492(\AA)$ & $\mathrm{C}(\mathrm{M})-\mathrm{C}(\mathrm{K})-\mathrm{C}(\mathrm{Q})$ & $121.47\left(^{\circ}\right)$ \\
\hline $\mathrm{P}(2)-\mathrm{O}(7)$ & $1.579(\AA)$ & $\mathrm{C}(\mathrm{K})-\mathrm{C}(\mathrm{M})-\mathrm{C}(\mathrm{K})$ & $116.30\left(^{\circ}\right)$ \\
\hline $\mathrm{P}(2)-\mathrm{O}(4)$ & $1.520(\AA)$ & $\mathrm{C}(1)-\mathrm{C}(\mathrm{J})-\mathrm{C}(1)$ & $117.51\left(^{\circ}\right)$ \\
\hline $\mathrm{C}(\mathrm{E})-\mathrm{P}(3)$ & $1.794(\AA)$ & $\mathrm{O}(5)-\mathrm{P}(3)-\mathrm{C}(\mathrm{E})$ & $107.11\left(^{\circ}\right)$ \\
\hline $\mathrm{C}(\mathrm{F})-\mathrm{P}(2)$ & $1.795(\AA)$ & $\mathrm{O}(4)-\mathrm{P}(2)-\mathrm{O}(7)$ & $108.08\left(^{\circ}\right)$ \\
\hline $\mathrm{C}(\mathrm{M})-\mathrm{C}(\mathrm{J})$ & $1.374(\AA)$ & $\mathrm{C}(\mathrm{E})-\mathrm{P}(3)-\mathrm{O}(8)$ & $105.52\left(^{\circ}\right)$ \\
\hline
\end{tabular}


Table S2. Unit cell parameters from HR-PXRD $\mathrm{H}_{8} \mathrm{~L}-\mathrm{Co}-\mathrm{Crystal}$ study for suspended in different dry organic solvents.

\begin{tabular}{|c|c|c|c|c|c|}
\hline Sample & RT & Benzene & Hexane & $\mathrm{CH}_{3} \mathrm{CN}$ & $\mathrm{CH}_{3} \mathrm{OH}$ \\
\hline $\begin{array}{l}\text { Crystal } \\
\text { system }\end{array}$ & Monoclinic & Monoclinic & Monoclinic & Monoclinic & Monoclinic \\
\hline Space group & $C 2 / c$ & $C 2 / c$ & $C 2 / c$ & $C 2 / c$ & $C 2 / c$ \\
\hline$a(\AA)$ & $29.364(8)$ & $29.364(8)$ & $29.364(8)$ & $29.364(8)$ & $29.364(8)$ \\
\hline$b(\AA)$ & $12.204(4)$ & $12.204(4)$ & $12.204(4)$ & $12.204(4)$ & $12.204(4)$ \\
\hline$c(\AA)$ & $9.925(3)$ & $9.925(3)$ & $9.925(3)$ & $9.925(3)$ & $9.925(3)$ \\
\hline$\alpha(\mathbf{o})$ & 90 & 90 & 90 & 90 & 90 \\
\hline$\beta(\mathbf{o})$ & $97.405(12)$ & $97.405(12)$ & $97.405(12)$ & $97.405(12)$ & $97.405(12)$ \\
\hline$\gamma(\mathbf{0})$ & 90 & 90 & 90 & 90 & 90 \\
\hline Colour & Pink & Pink & Pink & Blue & Blue \\
\hline
\end{tabular}




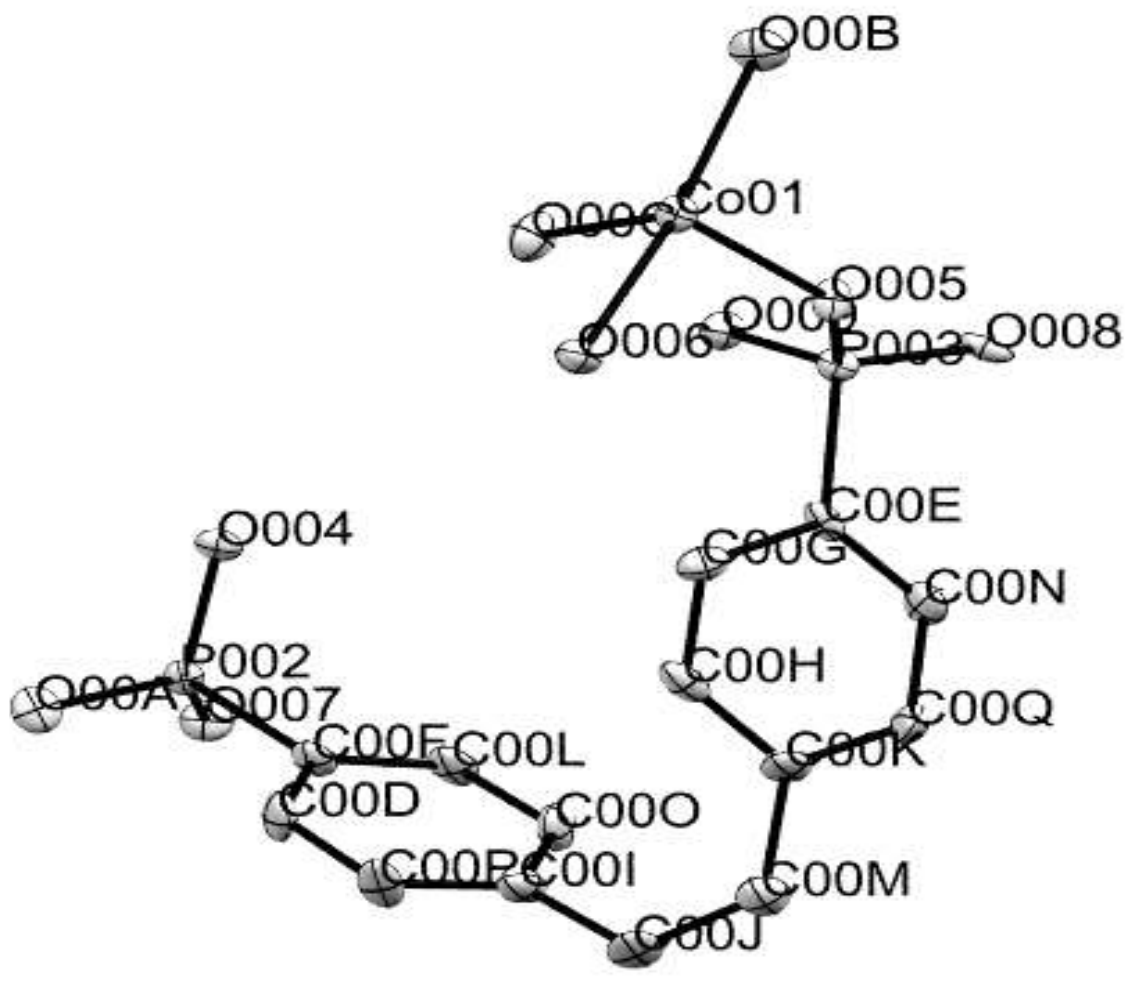

Fig. S1 ORTEP model of the asymmetric unit of $\mathrm{H}_{8} \mathrm{~L}-\mathrm{Co}-\mathrm{Crystal}$. 


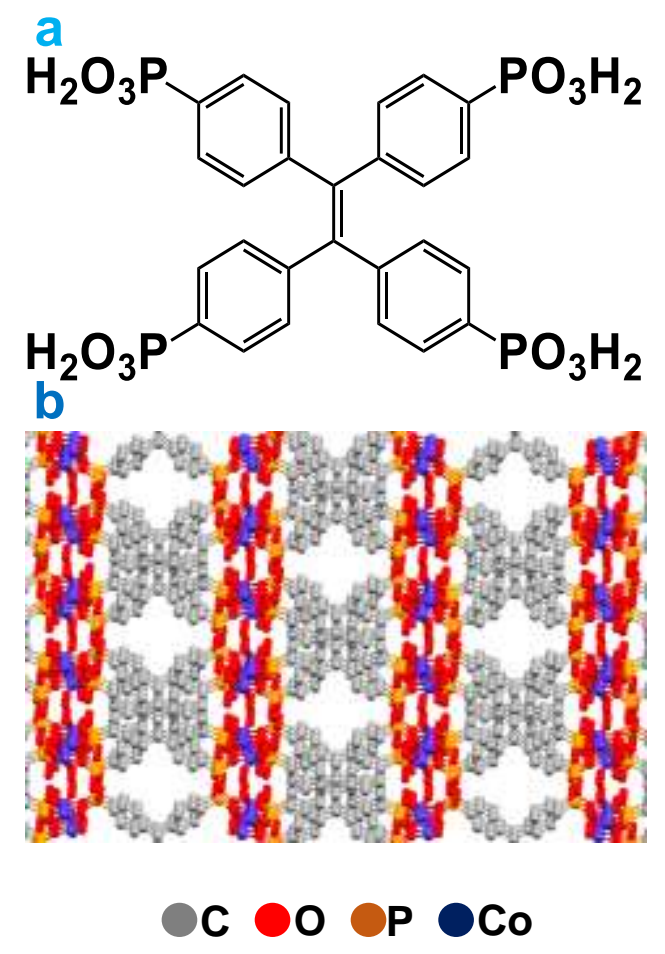

Fig S2. The phosphonate based $\mathrm{H}_{8} \mathrm{~L}$ ligand structure (a) and 3D network type framework of the Co-MOF (b). 


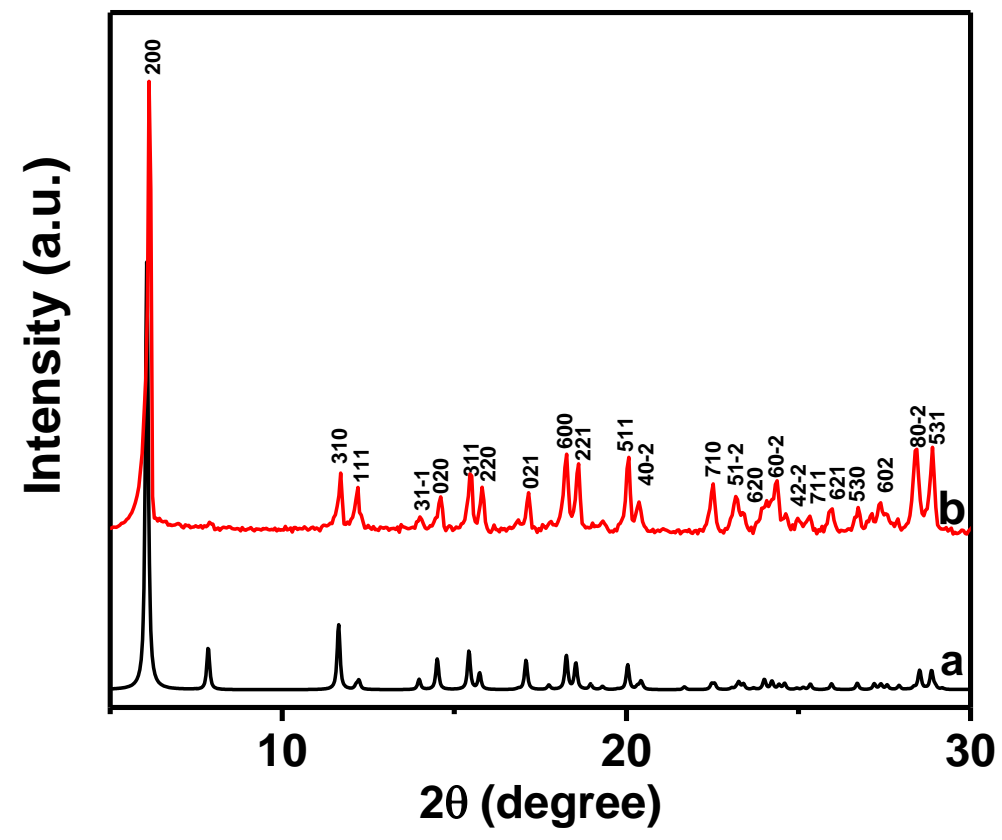

Fig. S3. PXRD pattern of $\mathrm{H}_{8} \mathrm{~L}-\mathrm{Co}-\mathrm{Crystal}$, a: simulated, b: as synthesized. 


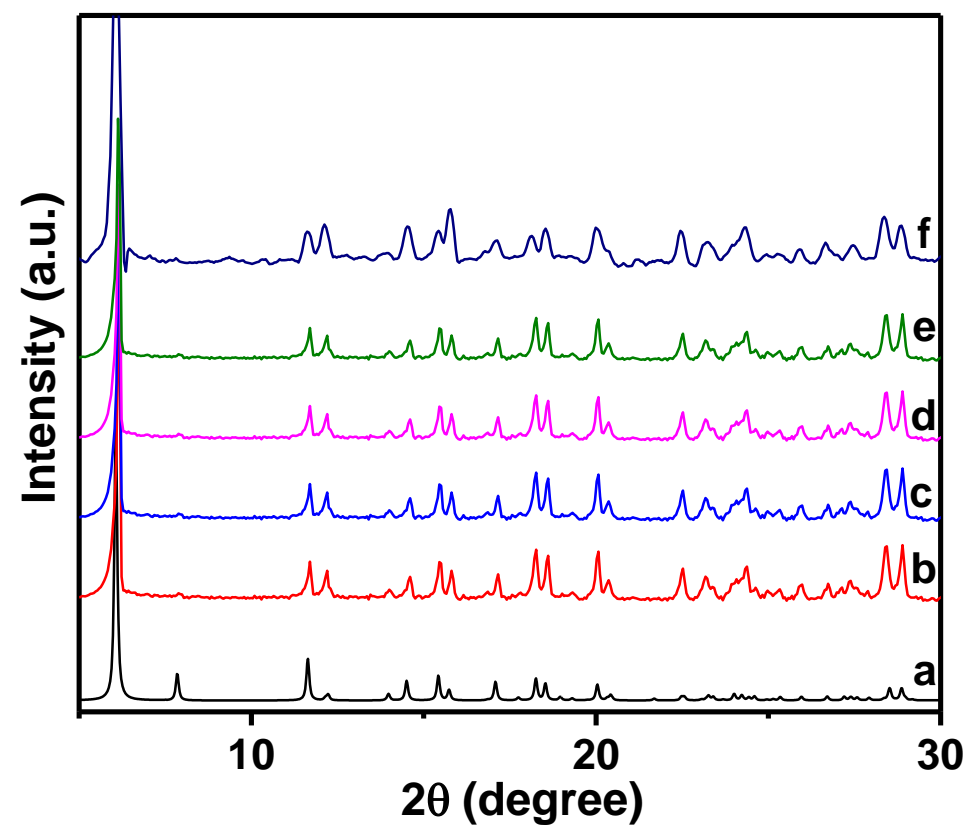

Fig. S4. PXRD pattern of $\mathrm{H}_{8} \mathrm{~L}-\mathrm{Co}-\mathrm{crystal}_{\text {at }}$ different $\mathrm{pH}$, a: simulated, $\mathrm{b}$ : $\mathrm{pH}=1.0, \mathrm{c}: \mathrm{pH}=3.0$, $\mathrm{d}: \mathrm{pH}=4.0$, e: $\mathrm{pH}=7.0$ and $\mathrm{f}: \mathrm{pH}=9.0$. 


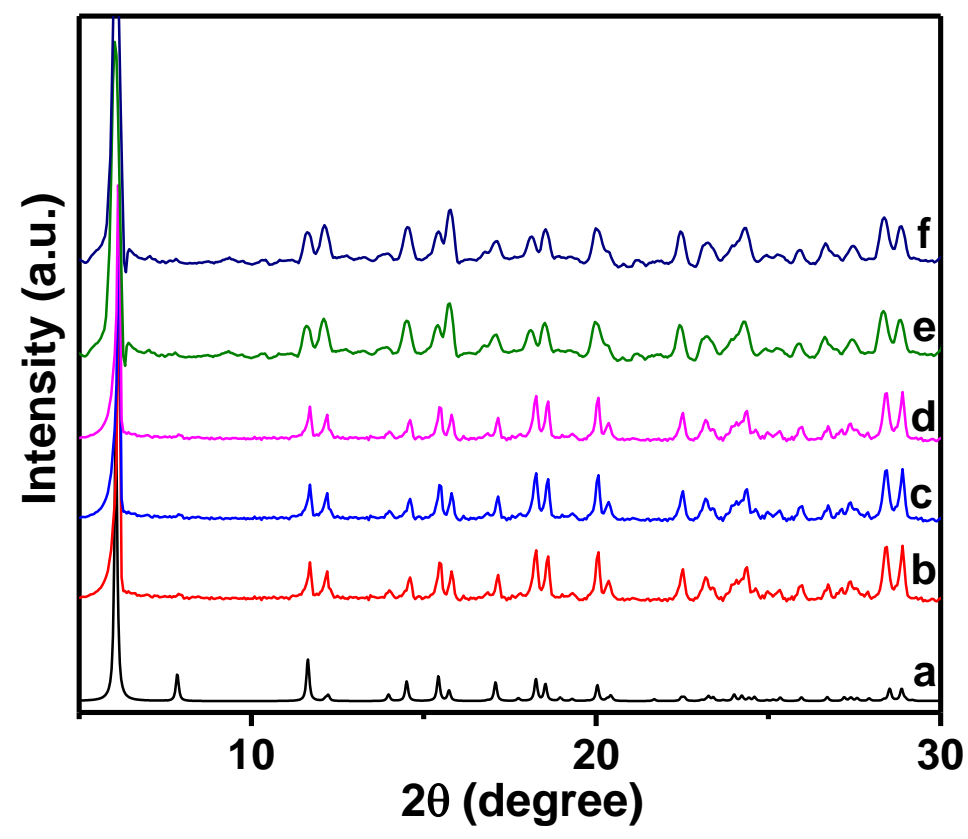

Fig. S5. Comparative PXRD data of $\mathrm{H}_{8} \mathrm{~L}-\mathrm{Co}$-crystal in different solvents for 60 days a; simulated, b; as synthesized, solvent exchanged with, c; benzene, d; hexane, e; acetonitrile, f; methanol. 


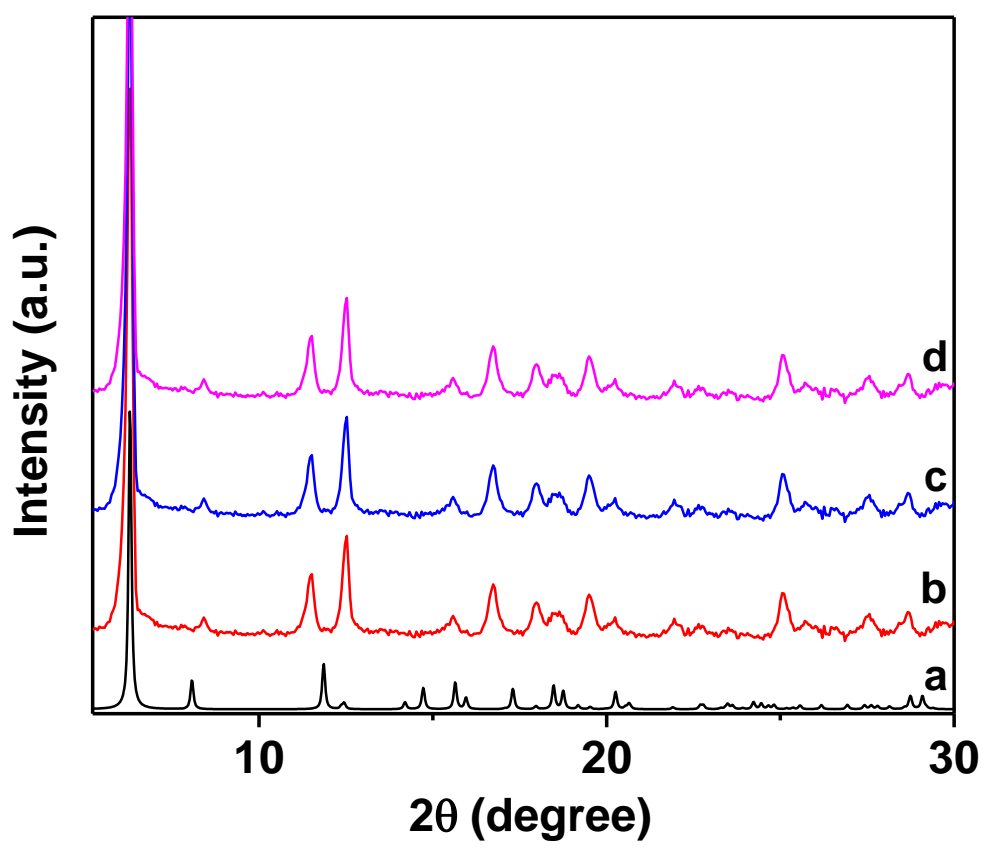

Fig. S6. Stability of $\mathrm{H}_{8} \mathrm{~L}-\mathrm{Co}-\mathrm{crystal}$ in different mixing solvents for 60 days, a: simulated, b: water, c: water+MeOH, d: $\mathrm{MeOH}+\mathrm{MeCN}$. 


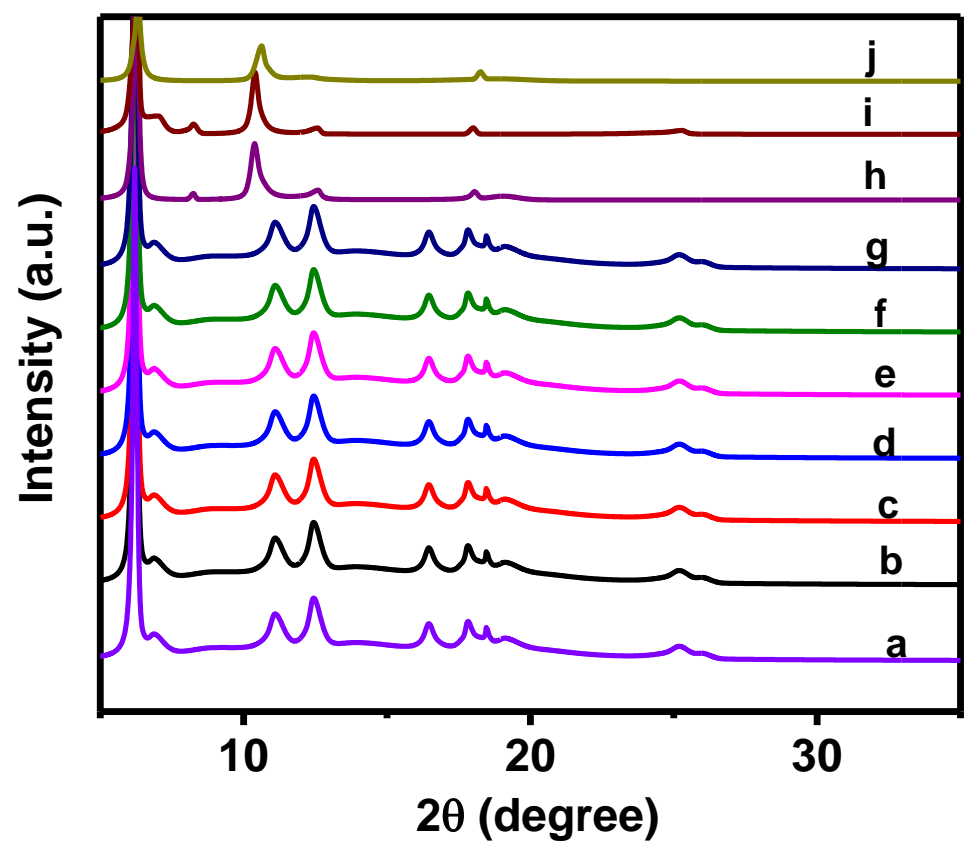

Fig. S7. Temperature dependent PXRD for $\mathrm{H}_{8} \mathrm{~L}-\mathrm{Co}$ MOF: 25 (a), 50 (b), 100 (c), 200 (d), 300 (e), 400 (f), 500 (g), 600 (h), 700 (i) and $800{ }^{\circ} \mathrm{C}$ (j). 


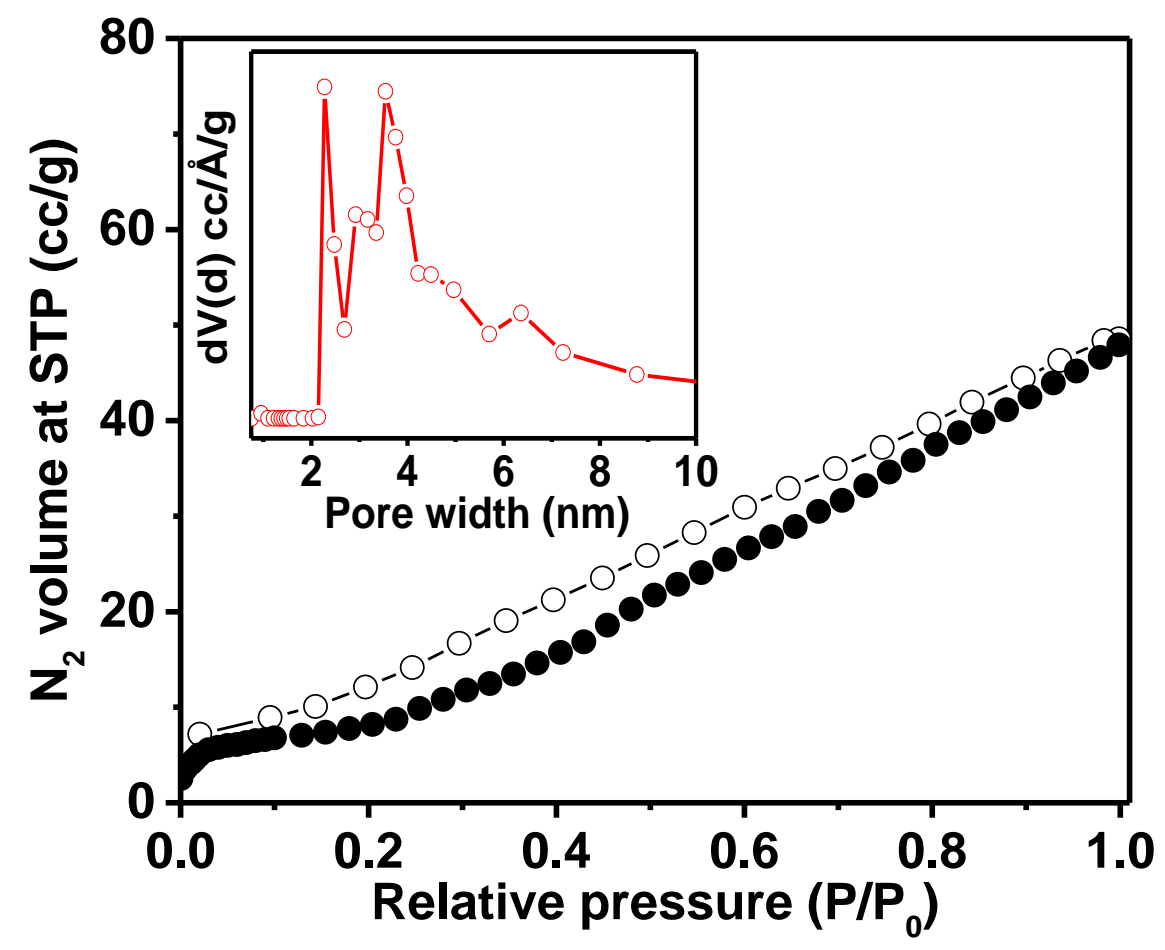

Fig. S8. $\mathrm{N}_{2}$ sorption isotherm (filled circle: adsorption, empty circle: desorption) of $\mathrm{H}_{8} \mathrm{~L}-\mathrm{Co}-$ Crystal MOF (inset; pore size distribution). 


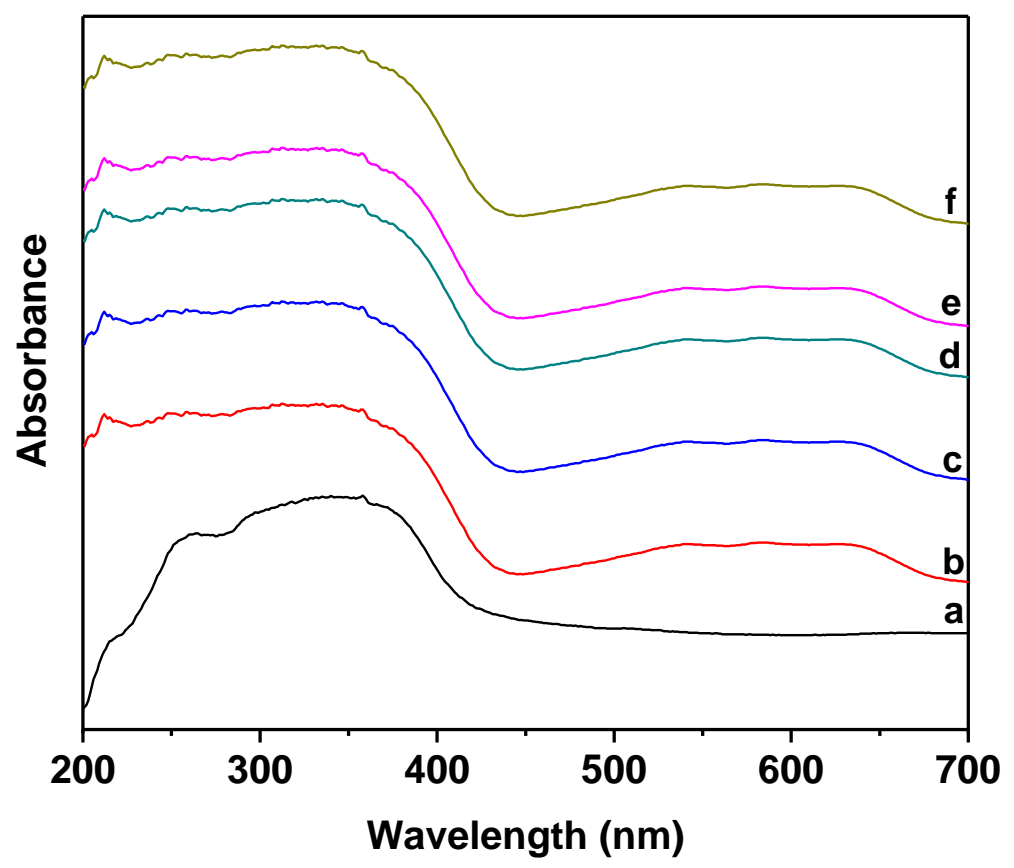

Fig. S9. UV-Vis DRS spectra of suspended $\mathrm{H}_{8} \mathrm{~L}-\mathrm{Co}-\mathrm{Crystal}$ in different polar and non-polar solvents, a: $\mathrm{H}_{8} \mathrm{~L}$, b: $\mathrm{H}_{8} \mathrm{~L}-\mathrm{Co}-\mathrm{Crystal}$, c: methanol, d: acetonitrile, e: benzene, f: hexane. 


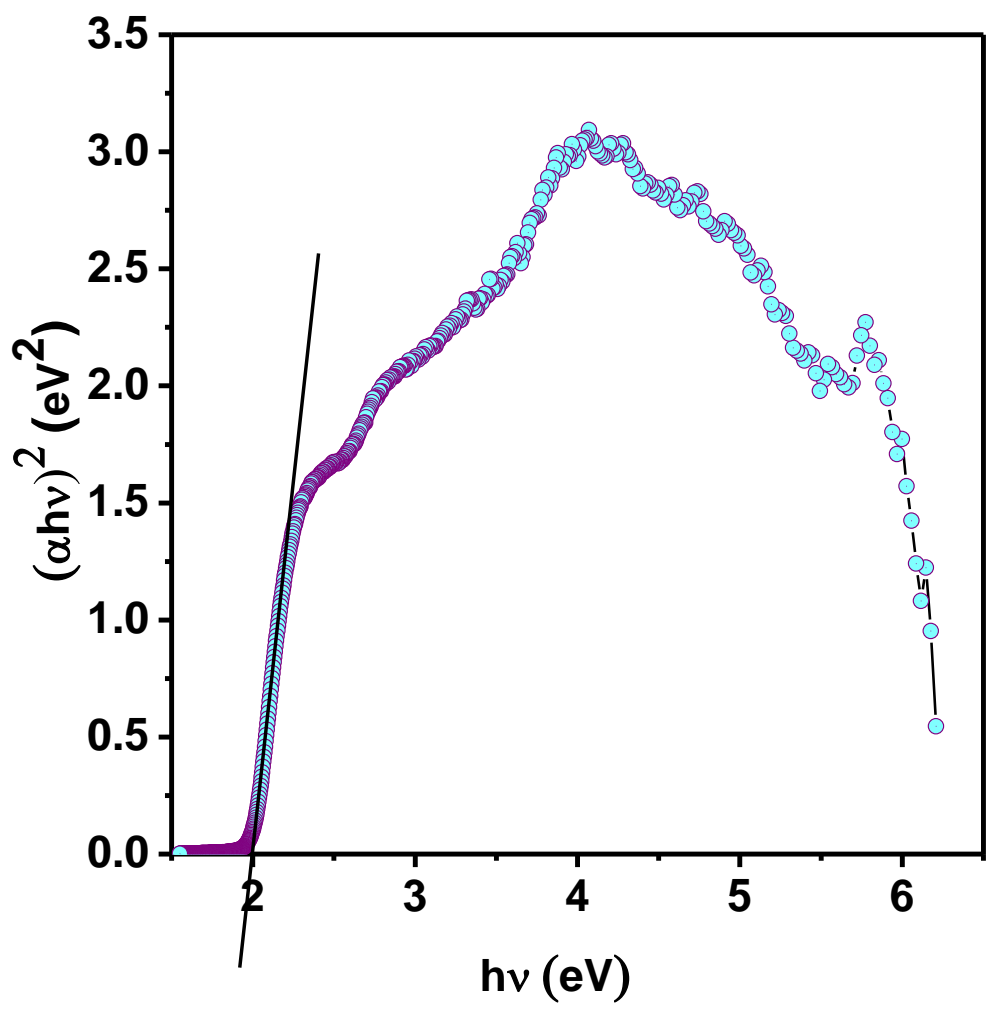

Fig. S10. The band gap calculation of $\mathrm{H}_{8} \mathrm{~L}-\mathrm{Co}-\mathrm{Crystal}$ using Tauc-Plot. 


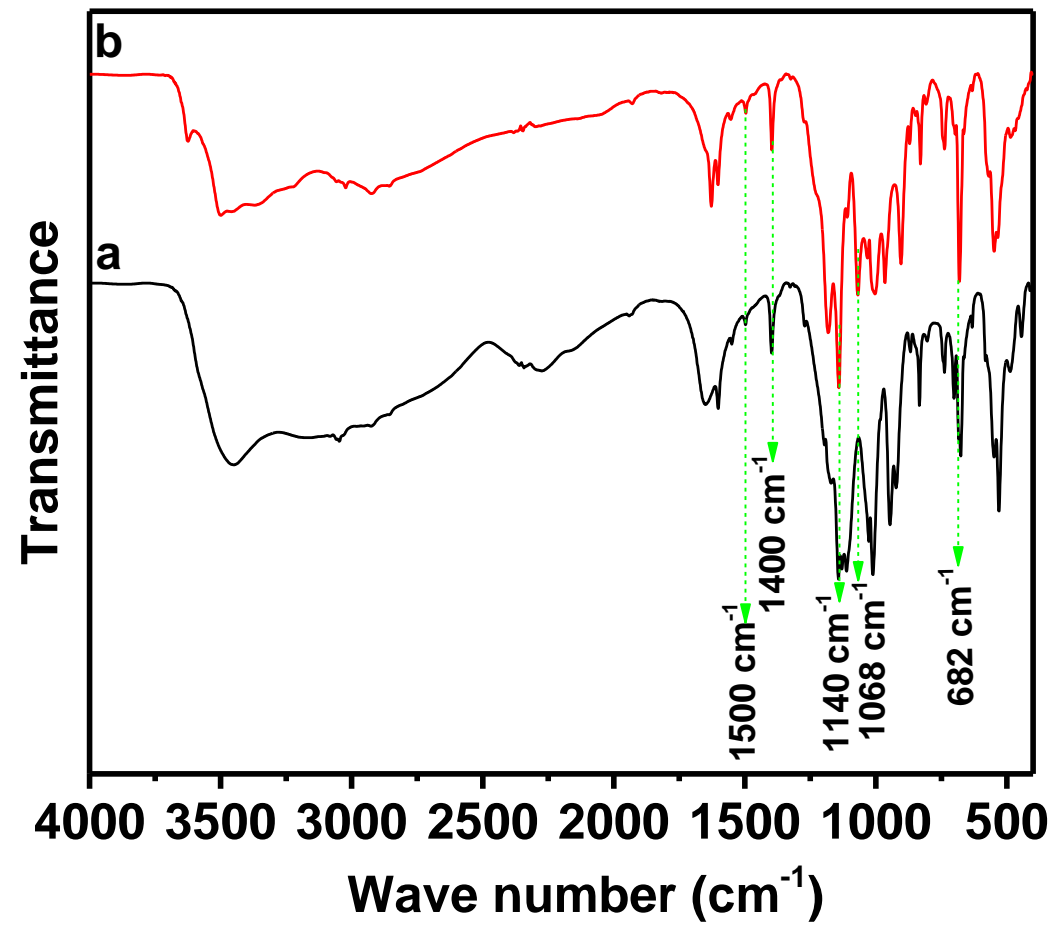

Fig. S11. FT-IR spectra of $\mathrm{H}_{8} \mathrm{~L}$ (a) and $\mathrm{H}_{8} \mathrm{~L}-\mathrm{Co}-\mathrm{Crystal}$ (b). 


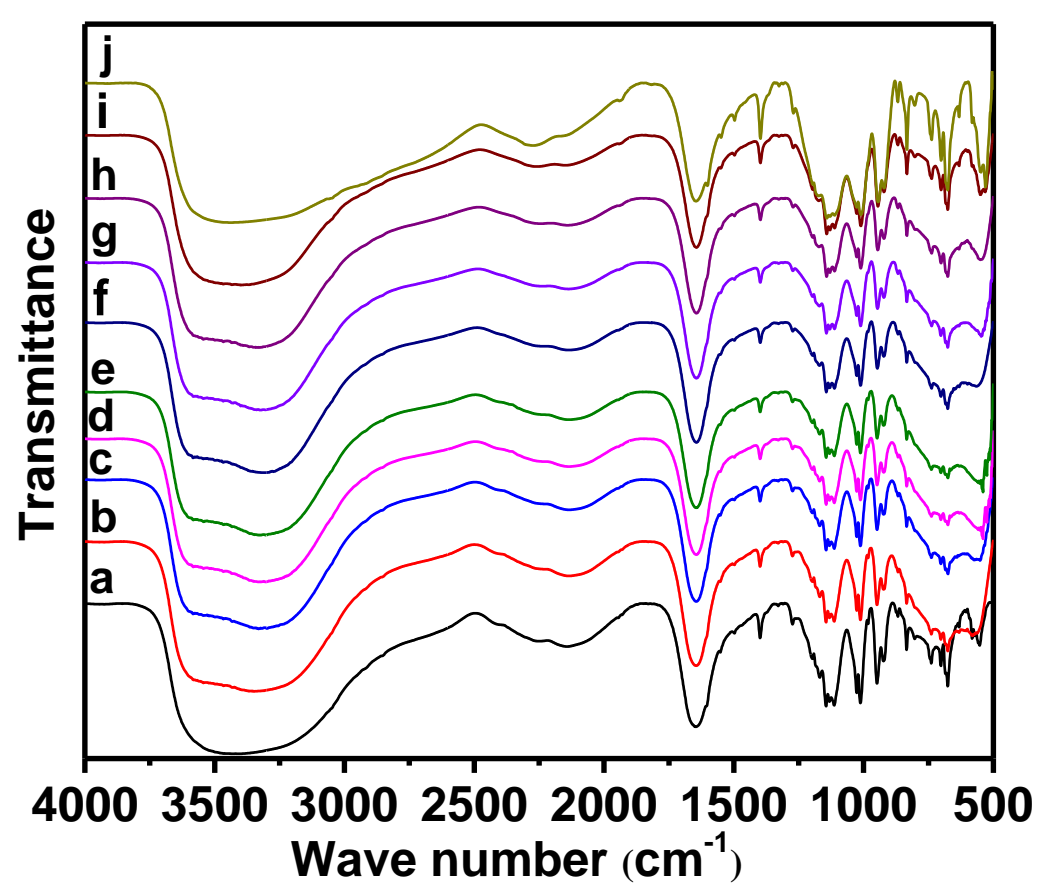

Fig. S12. In situ variable temperature FT-IR of $\mathrm{H}_{8} \mathrm{~L}-\mathrm{Co}-\mathrm{Crystal}$ a: 148, b: 173, c: 198, d: 223 , e: 248, f: 273, g: 298, h: 323, i: 348 and j: $373 \mathrm{~K}$. 


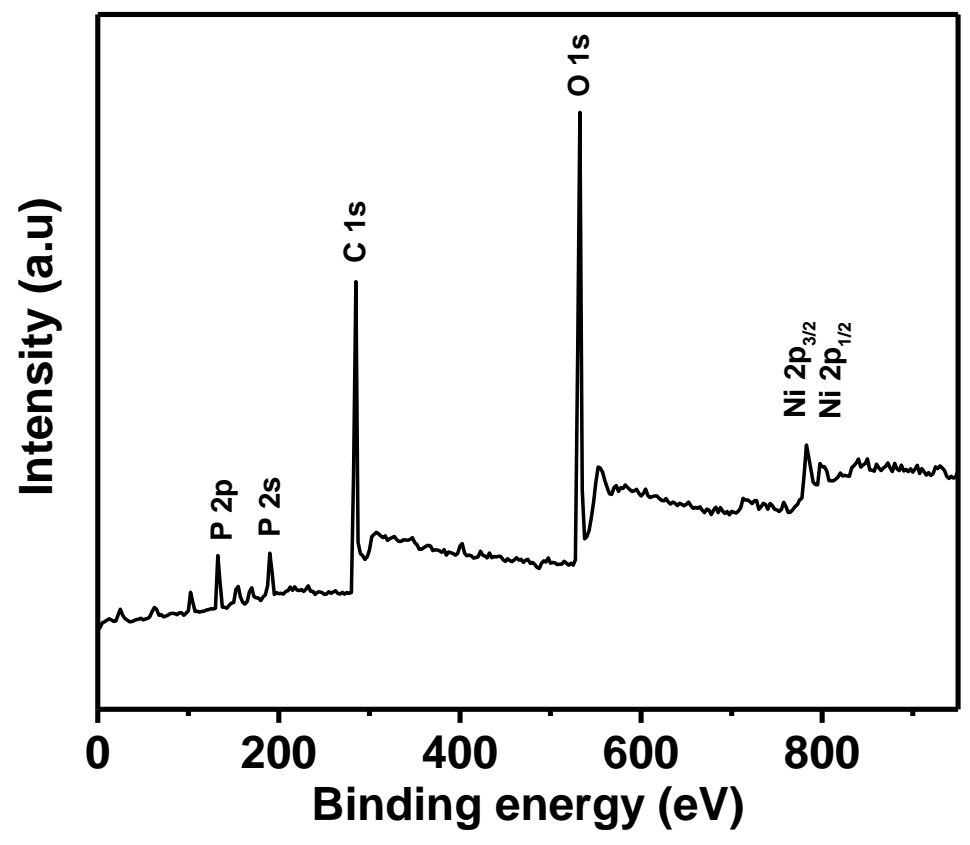

Figure S13. Full view XPS spectrum of as synthesized $\mathrm{H}_{8} \mathrm{~L}-$ Co-crystal. 

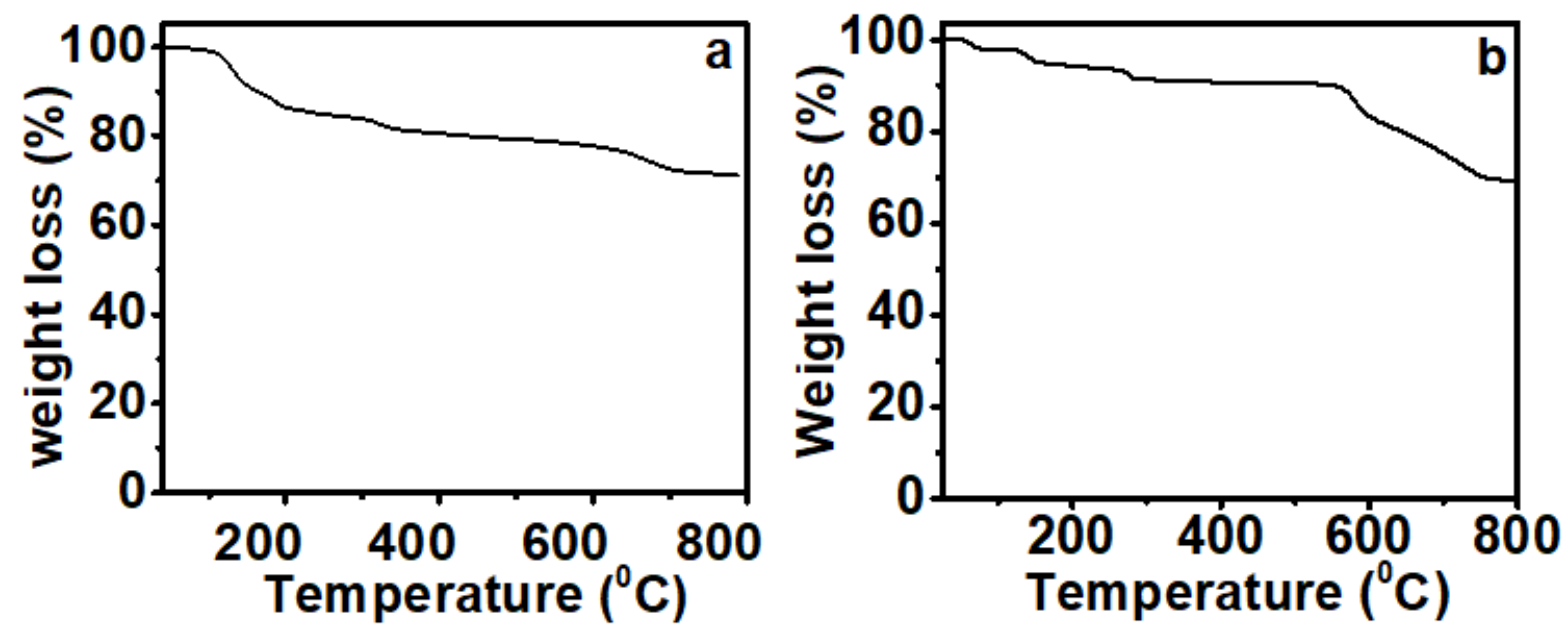

Fig. S14. TG-DTA profiles of $\mathrm{H}_{8} \mathrm{~L}-\mathrm{Co}-\mathrm{Crystal}$ recorded under $\mathrm{N}_{2}$ (a) and air (b) atmosphere. 

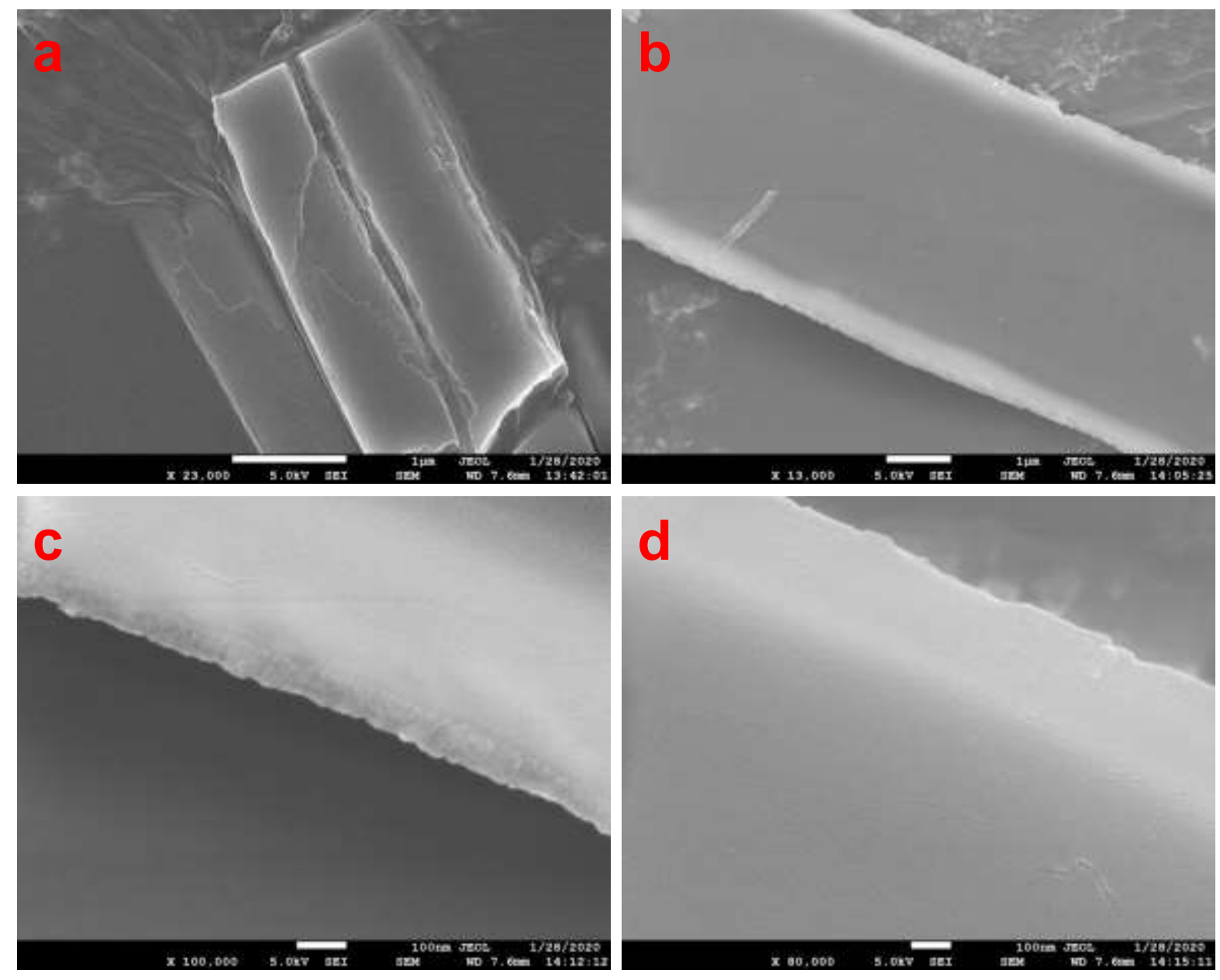

Fig. S15. The rectangular block shaped crystal of the $\mathrm{H}_{8} \mathrm{~L}-\mathrm{Co}-\mathrm{Crystal}$ from different side of view with different magnification. 


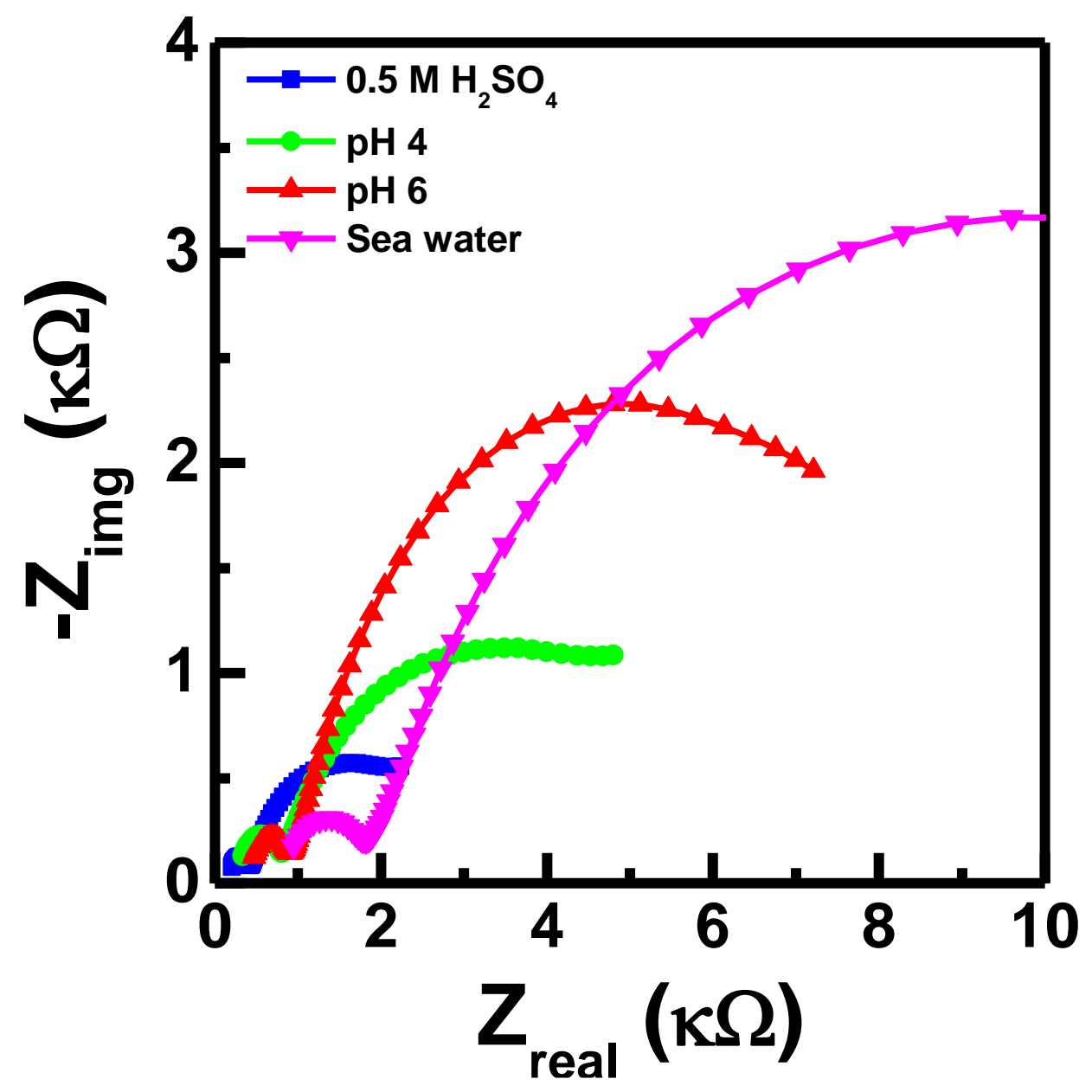

Fig. S16. The electrochemical impedance spectroscopy of $\mathrm{H}_{8} \mathrm{~L}-\mathrm{Co} \mathrm{MOF}$ in various electrolytic mediums. 

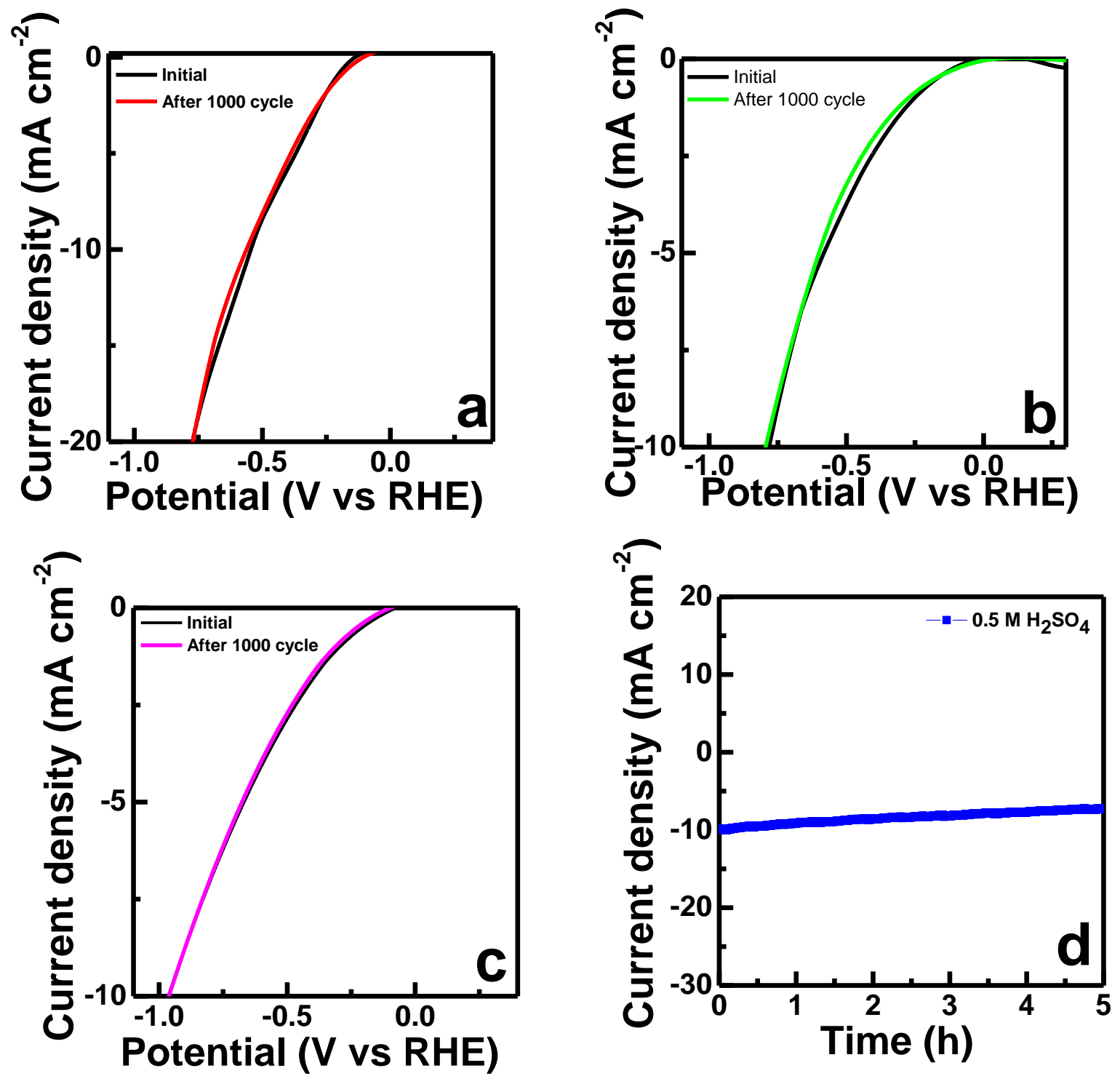

Fig. S17. LSV plot before and after $1000 \mathrm{CV}$ cycles in (a) $\mathrm{pH}=4$, (b) $\mathrm{pH}=6$, (c) sea water medium and (d) chrono-amperometry curve upto $5 \mathrm{~h}$ in $0.5 \mathrm{M} \mathrm{H}_{2} \mathrm{SO}_{4}$ medium using graphite electrode. 

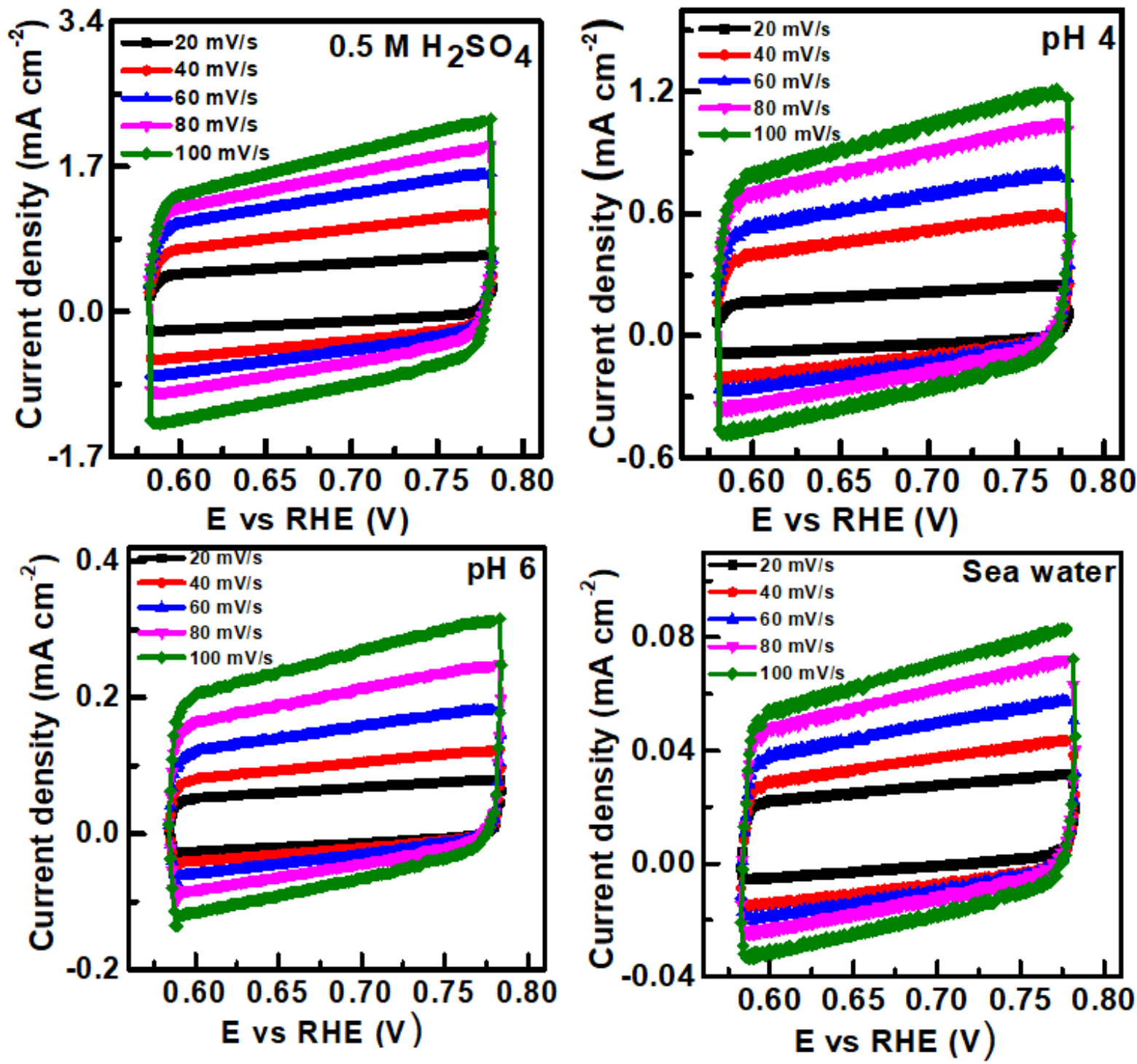

Fig. S18. Cyclic voltammograms obtained from the non- Faradic region of $\mathrm{H}_{8} \mathrm{~L}-\mathrm{Co}-\mathrm{Crystal}$ MOF at different scan rates in different electrolyte medium. 

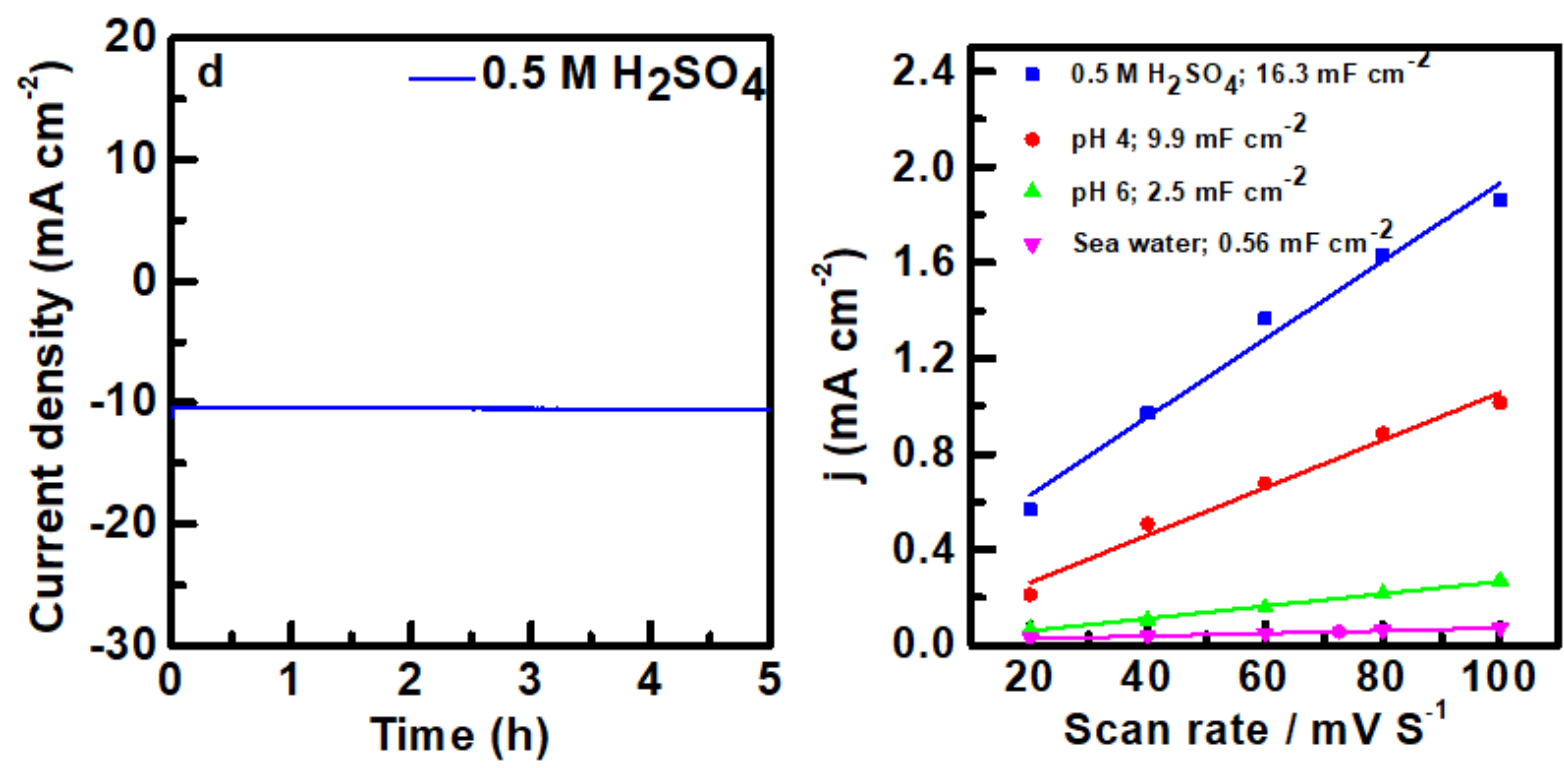

Fig. S19. (a) chrono-amperometry curve upto 5 hours in $0.5 \mathrm{M} \mathrm{H}_{2} \mathrm{SO}_{4}$ medium using $\mathrm{Pt} / \mathrm{C}$ electrode (b) Cdl calculation of $\mathrm{H}_{8} \mathrm{~L}-\mathrm{Co}-\mathrm{Crystal} \mathrm{MOF}$ in different electyrolyte medium. 


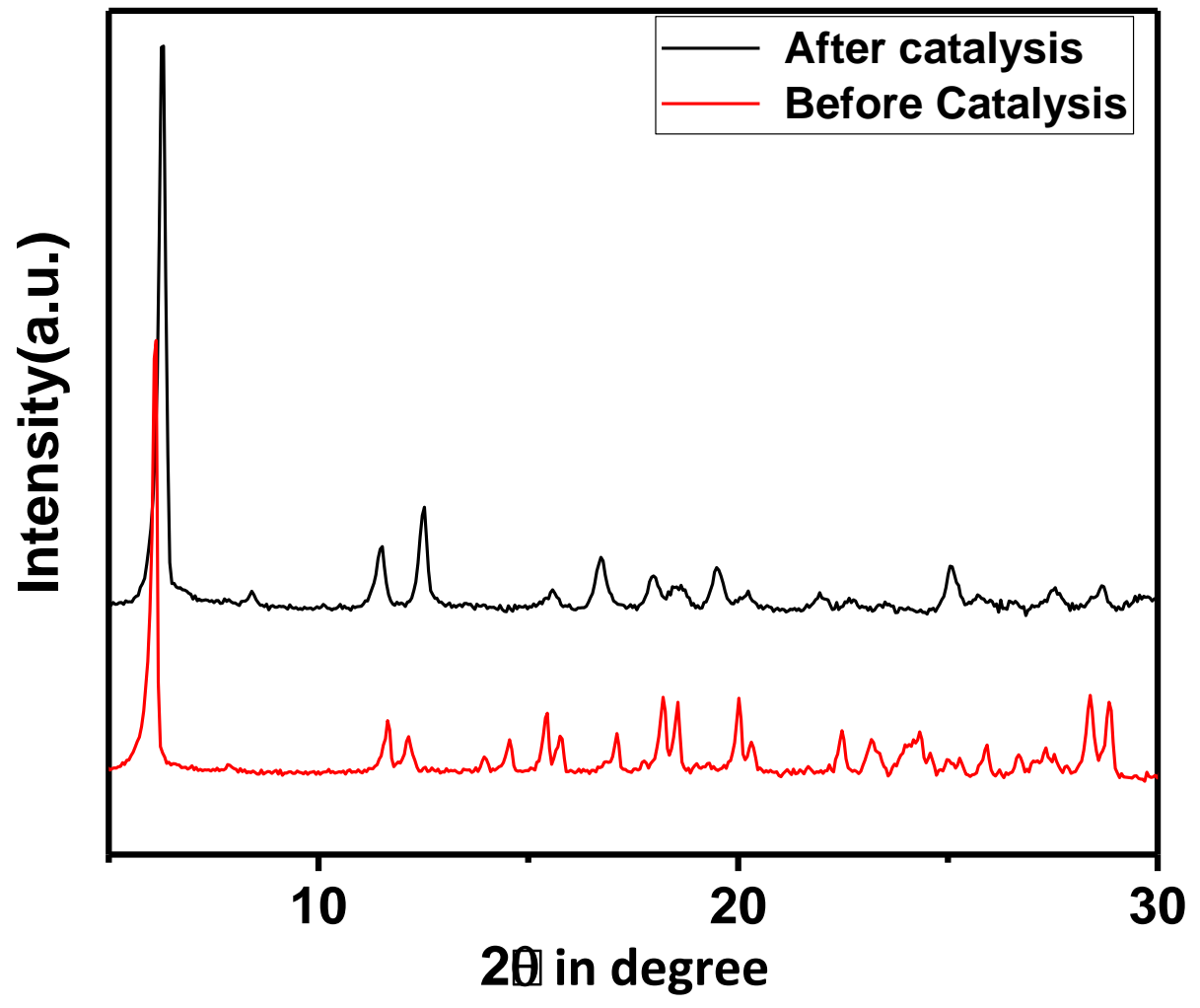

Fig. S20. PXRD pattern of $\mathrm{H}_{8} \mathrm{~L}-\mathrm{Co}-\mathrm{Crystal}$ before and after catalytic cycle. 


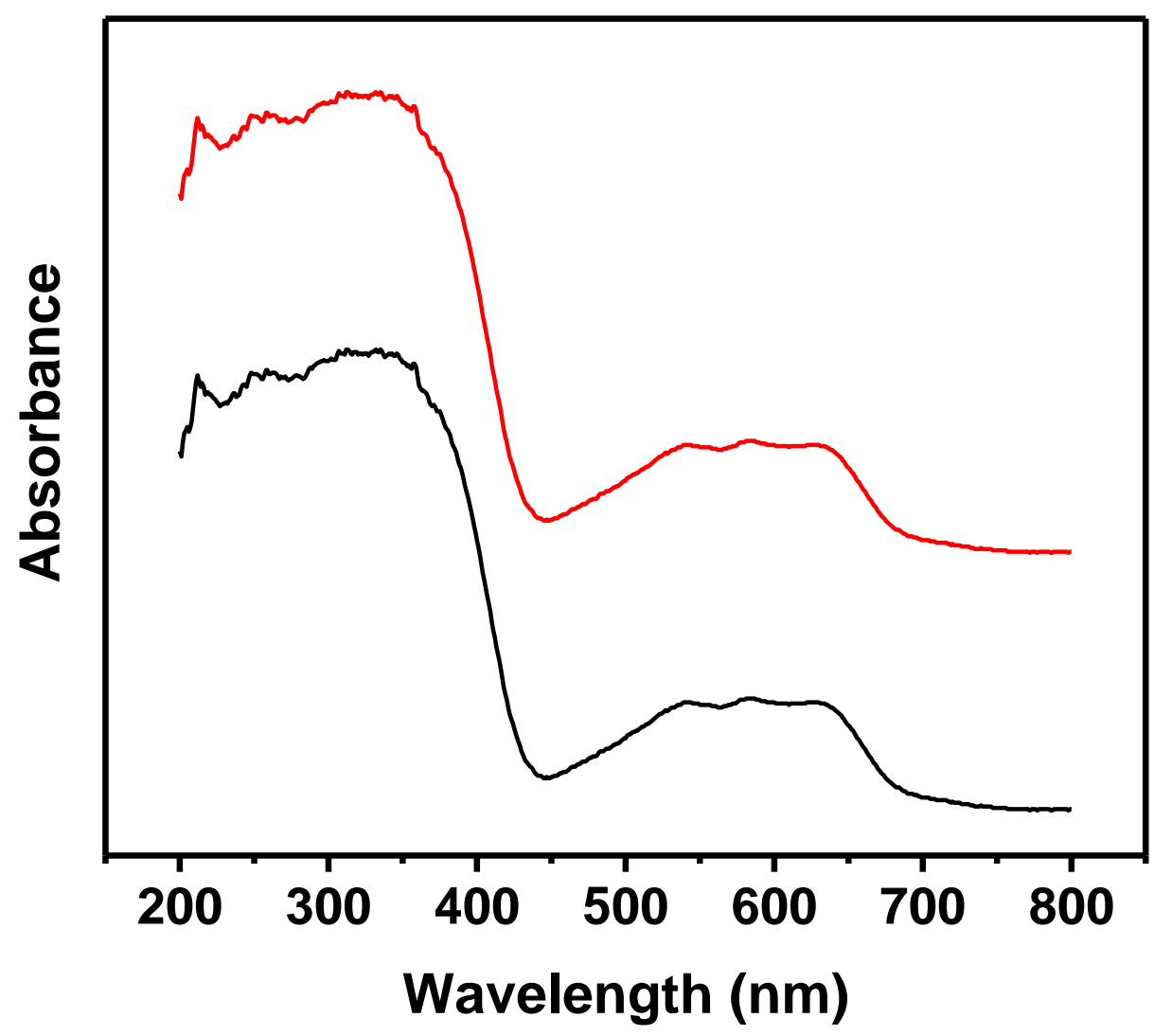

Fig. S21. UV-vis spectrum of $\mathrm{H}_{8} \mathrm{~L}-\mathrm{Co}-\mathrm{Crystal}$ before (red) and after (black) catalysis. 


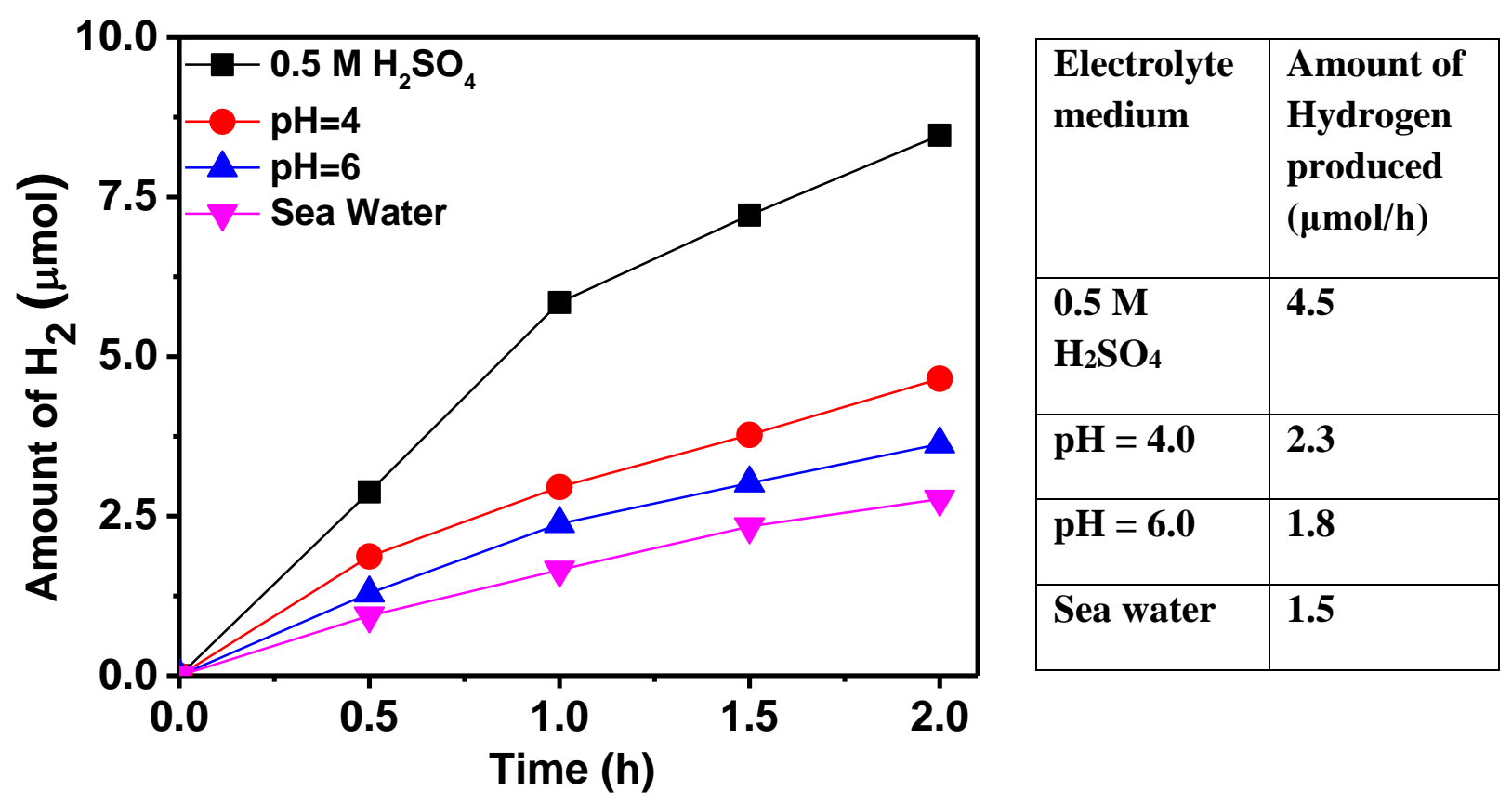

Figure S22. $\mathrm{H}_{2}$ evolution rate in different time interval over $\mathrm{H}_{8} \mathrm{~L}-\mathrm{Co}-\mathrm{Crystal}$, black: 0.5 (M) $\mathrm{H}_{2} \mathrm{SO}_{4}$, red: $\mathrm{pH}$ 4, blue: $\mathrm{pH}$ 6, pink: sea water. 


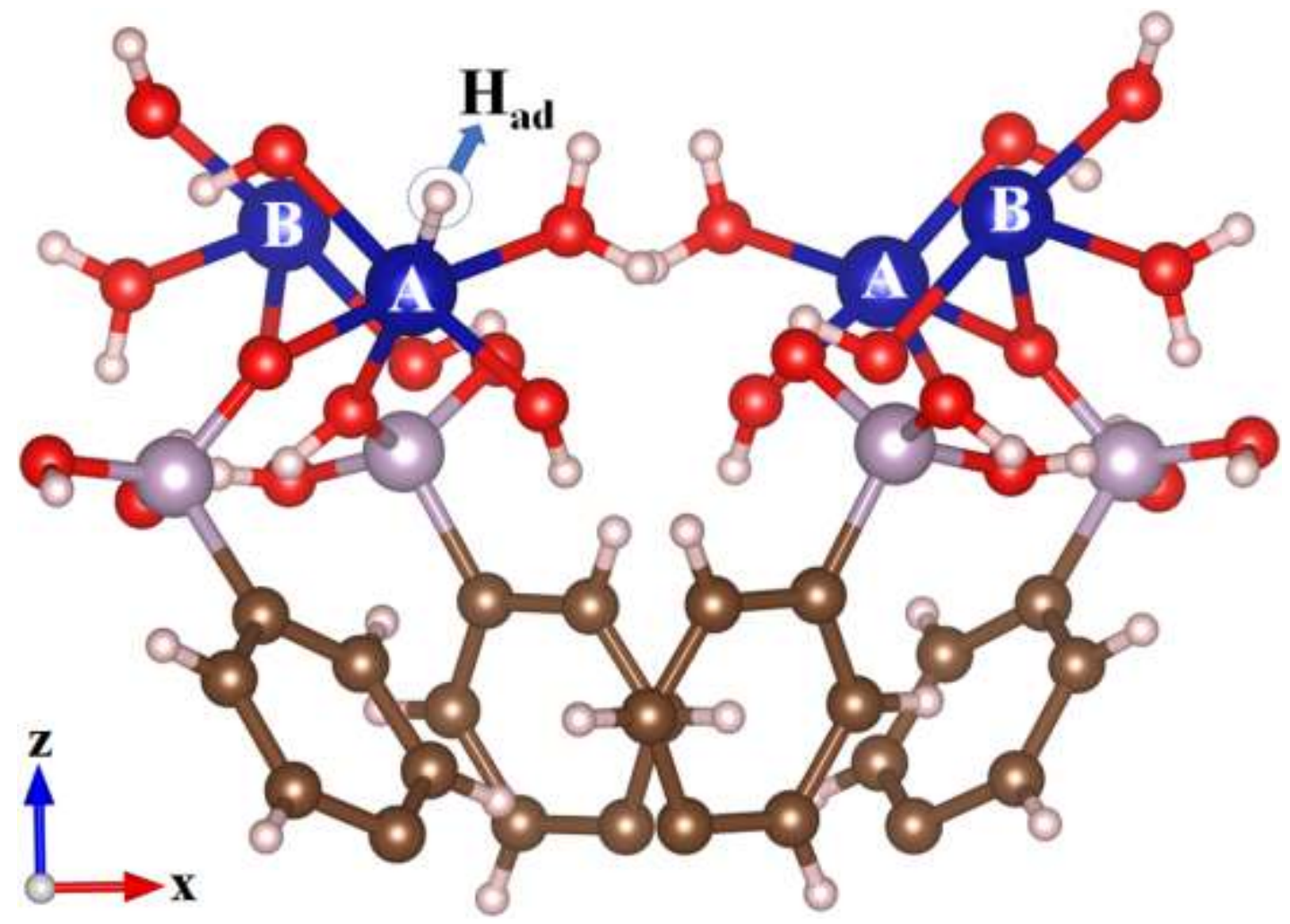

Fig. S23. Optimized structure of $\mathrm{H}^{*}$ adsorbed (on A-site of Co) $\mathrm{H}_{8} \mathrm{~L}-\mathrm{Co}-\mathrm{Crystal}$ (200) surface. 


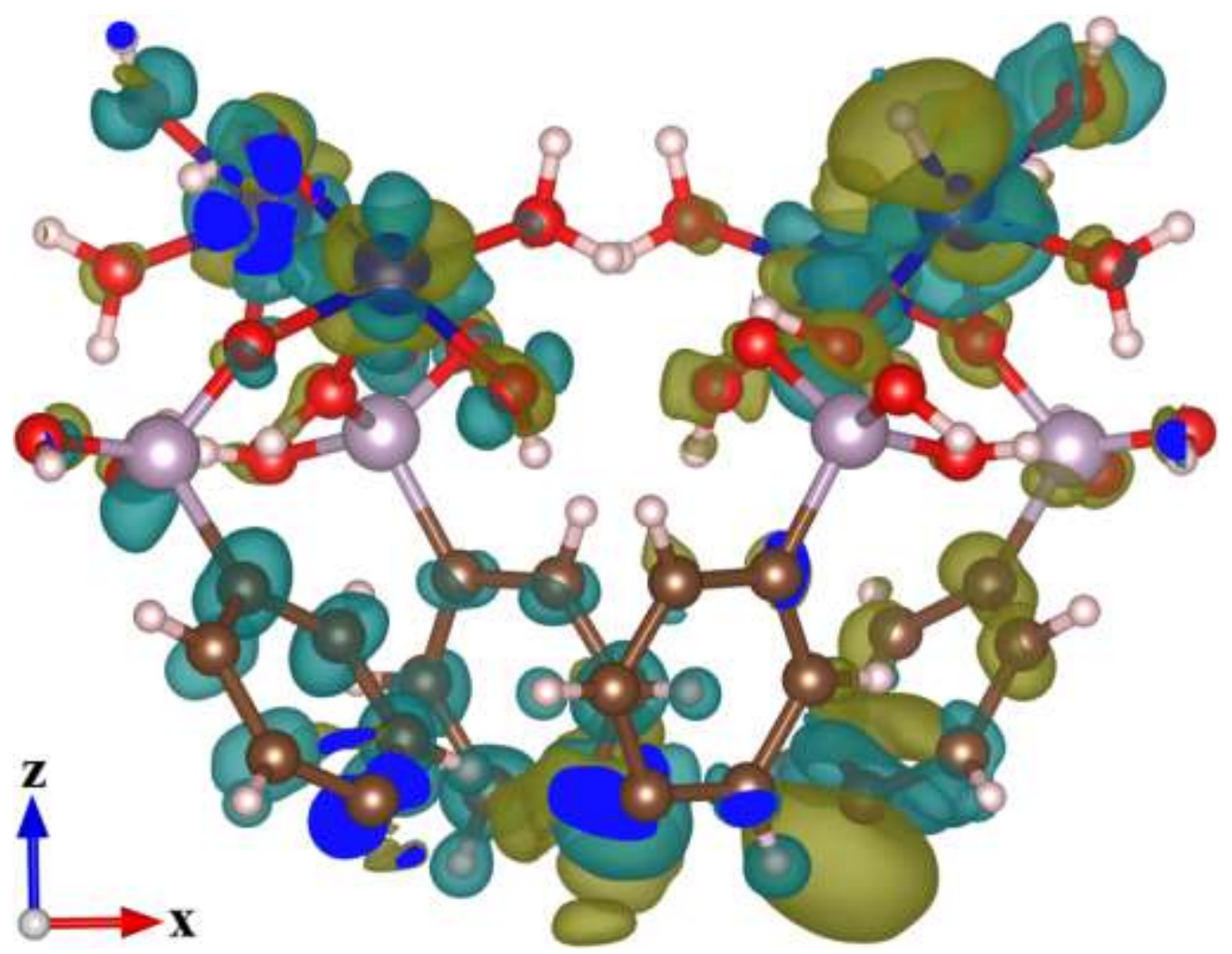

Fig. S24: Charge density difference (CDD) plot (isodensity value at surfaces is $\pm 0.002 \mathrm{e} / \mathrm{au}^{3}$ (Positive: cyan and Negative: olive) of $\mathrm{H}^{*}$ adsorbed $\mathrm{H}_{8} \mathrm{~L}-\mathrm{Co}-\mathrm{Crystal}$ (200) surface. 


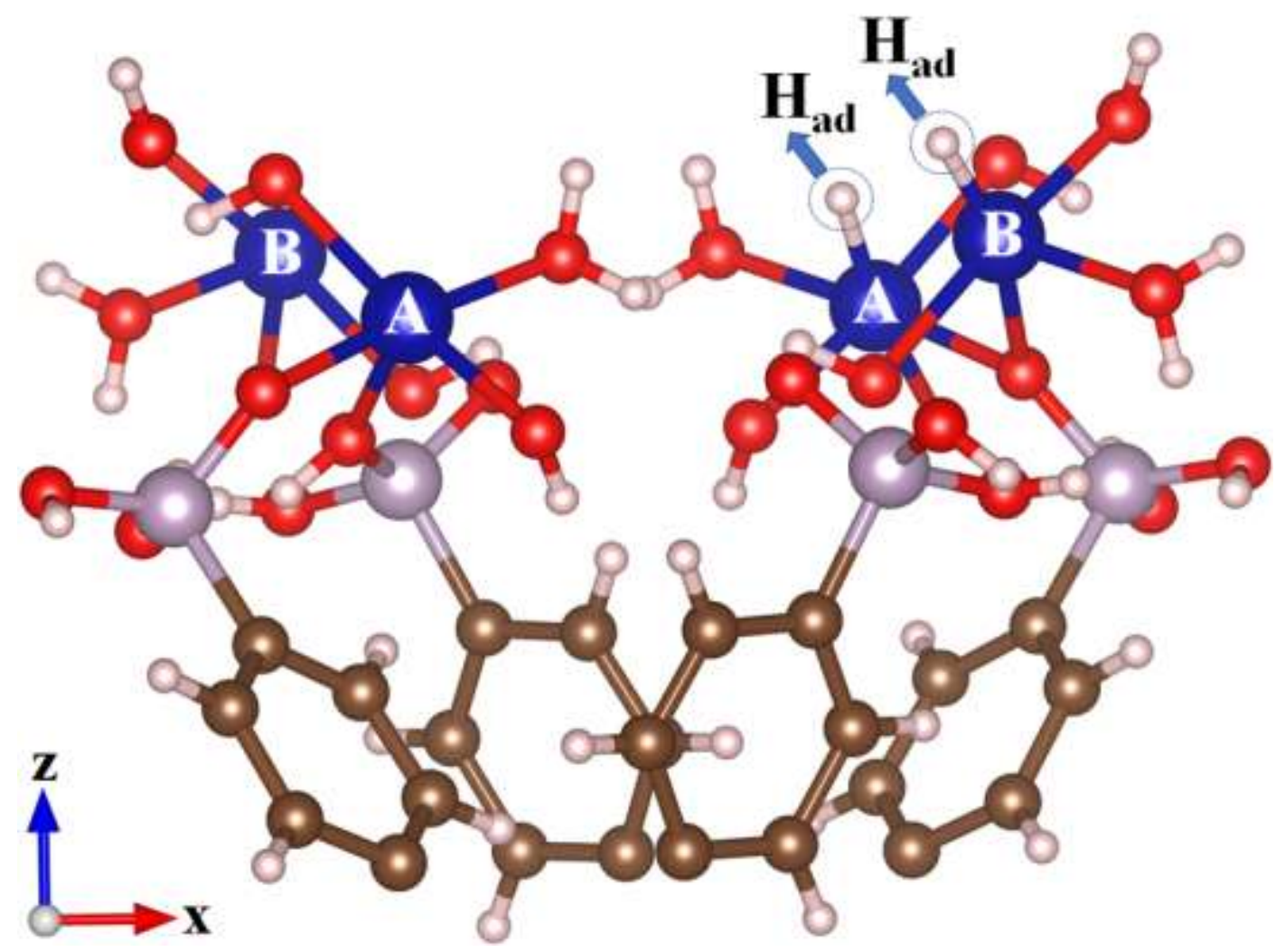

Fig. S25: Optimized structure of $\mathrm{H}_{8} \mathrm{~L}-\mathrm{Co}-\mathrm{Crystal}$ (200) surface after second $\mathrm{H}^{*}$ adsorption on $\mathrm{H}^{*}-\mathrm{H}_{8} \mathrm{~L}-\mathrm{Co}-\mathrm{Crystal}(200)$. 


\section{Section S8: Synthesis procedure of $\mathrm{HsL}-$ Ligand}

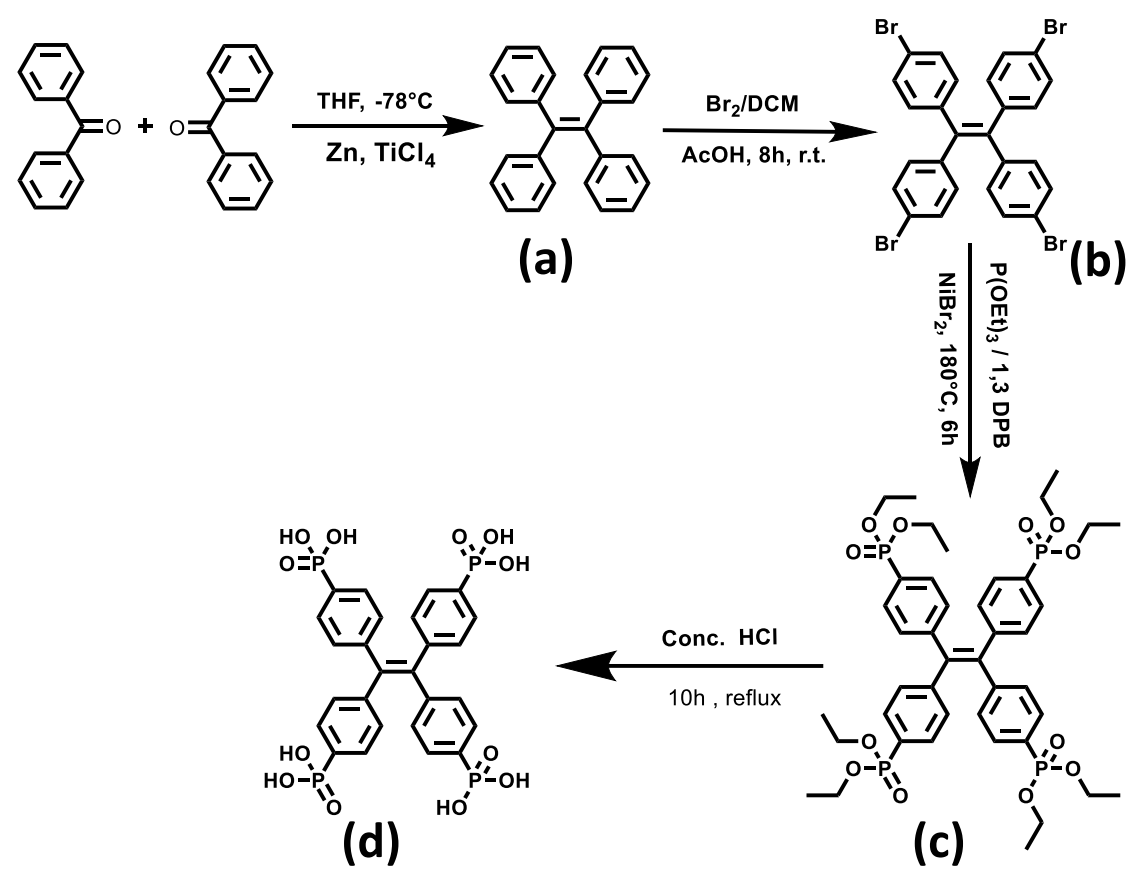

Scheme: Schematic presentation of the synthesis of $\mathrm{H}_{8} \mathrm{~L}$ Ligand.

I. Synthesis of TPE (a): 1,1,2,2-tetraphenylethylene (TPE) was synthesised by following reported procedure. ${ }^{1}$ In this typical synthetic procedure $30 \mathrm{~g}$ of zinc powder (459 mmol) was taken in a $500 \mathrm{ml}$ dried two neck round bottom flask and $150 \mathrm{~mL}$ of anhydrous THF added to it, then RB was degassed by purging nitrogen for $30 \mathrm{~min}$. The system was cooed down to $40^{\circ} \mathrm{C}$ dry ice/ $\mathrm{CH}_{3} \mathrm{CN}$ bath. Then a very slow addition of $150 \mathrm{~mL}$ of titanium (IV) chloride (228 mmol) was carried out followed by stirring and after completion of addition bath was allowed to attain room temperature, then heated $90^{\circ} \mathrm{C}$ for $2 \mathrm{~h}$ on an oil bath. The reaction mixture is cooled again on $0^{\circ} \mathrm{C}$ followed by addition of $23 \mathrm{~g}$ bezophenone $(150 \mathrm{mmol})$. The final mixture was transferred to oil bath and temperature raised to $90^{\circ} \mathrm{C}$ again and stirred overnight. After completion of reaction, mixture was cooled down and quenched on $400 \mathrm{ml}$ $10 \%$ aqueous solution of potassium carbonate; product was separated by dissolving on DCM. The final product was collected by evaporating DCM, and confirmed from ${ }^{1} \mathrm{H}$ NMR spectrum (500 MHz, CDCl3, $298 \mathrm{~K}) \delta=7.03-7.06 \mathrm{ppm}(\mathrm{m}, 8 \mathrm{H}), 7.09-7.13 \mathrm{ppm}(\mathrm{m}, 12 \mathrm{H})$. (Figure S26) 


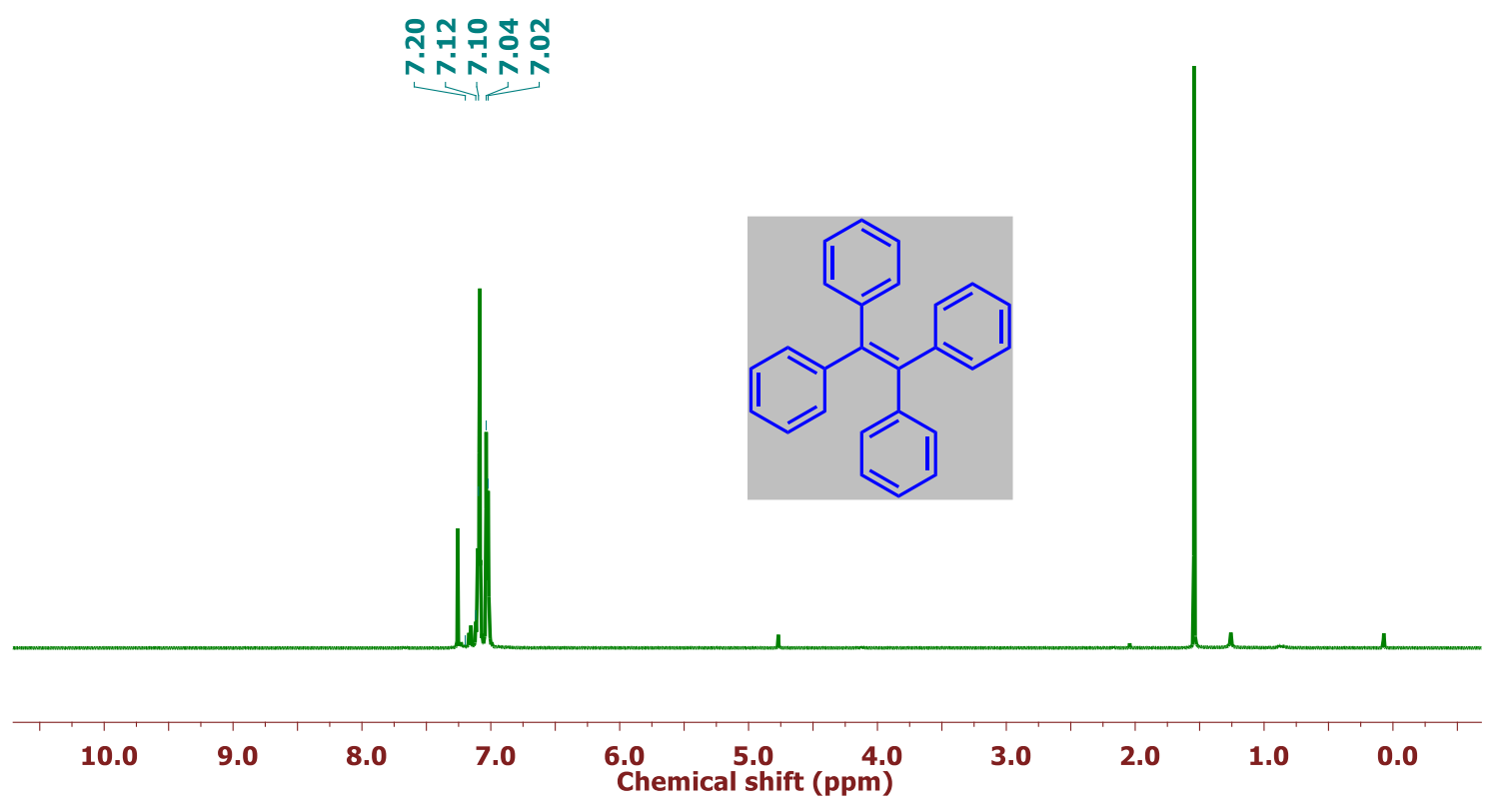

Figure S26: ${ }^{1} \mathrm{H}$ NMR of TPE (a).

II. Synthesis of TPE-Br (b): 1,1,2,2-tetrakis(4-bromophenyl) ethane (TPE-Br) was synthesized by bromination of TPE by following a previously reported procedure. ${ }^{2}$ The typical procedure followed such as, $4 \mathrm{~g}$ of TPE $(12.04 \mathrm{mmol})$ was taken in a $500 \mathrm{ml}$ dry round bottom flask then $150 \mathrm{~mL}$ dichloromethane and $50 \mathrm{~mL}$ of acetic acid were added, then the whole solution cooled to $0{ }^{0} \mathrm{C}$ in ice/water bath. To the cooled solution $4 \mathrm{~g}$ of bromine $(50$ mmol) was added slowly with constant stirring. The final reaction mixture was then allowed to stir overnight at room temperature. On completion of reaction the mixture was washed with $\mathrm{Na}_{2} \mathrm{~S}_{2} \mathrm{O}_{3}$ and product was collected by solvent extraction with DCM. The crude product was recrystallized and characterised by taking ${ }^{1} \mathrm{H}$ NMR spectrum. (400 $\mathrm{MHz}, \mathrm{CDCl}_{3}, 298 \mathrm{~K}$ ) $\delta=6.77-6.78 \mathrm{ppm}(\mathrm{d}, 8 \mathrm{H}), 7.19-7.20 \mathrm{ppm}(\mathrm{d}, 8 \mathrm{H})$ (Figure S27).

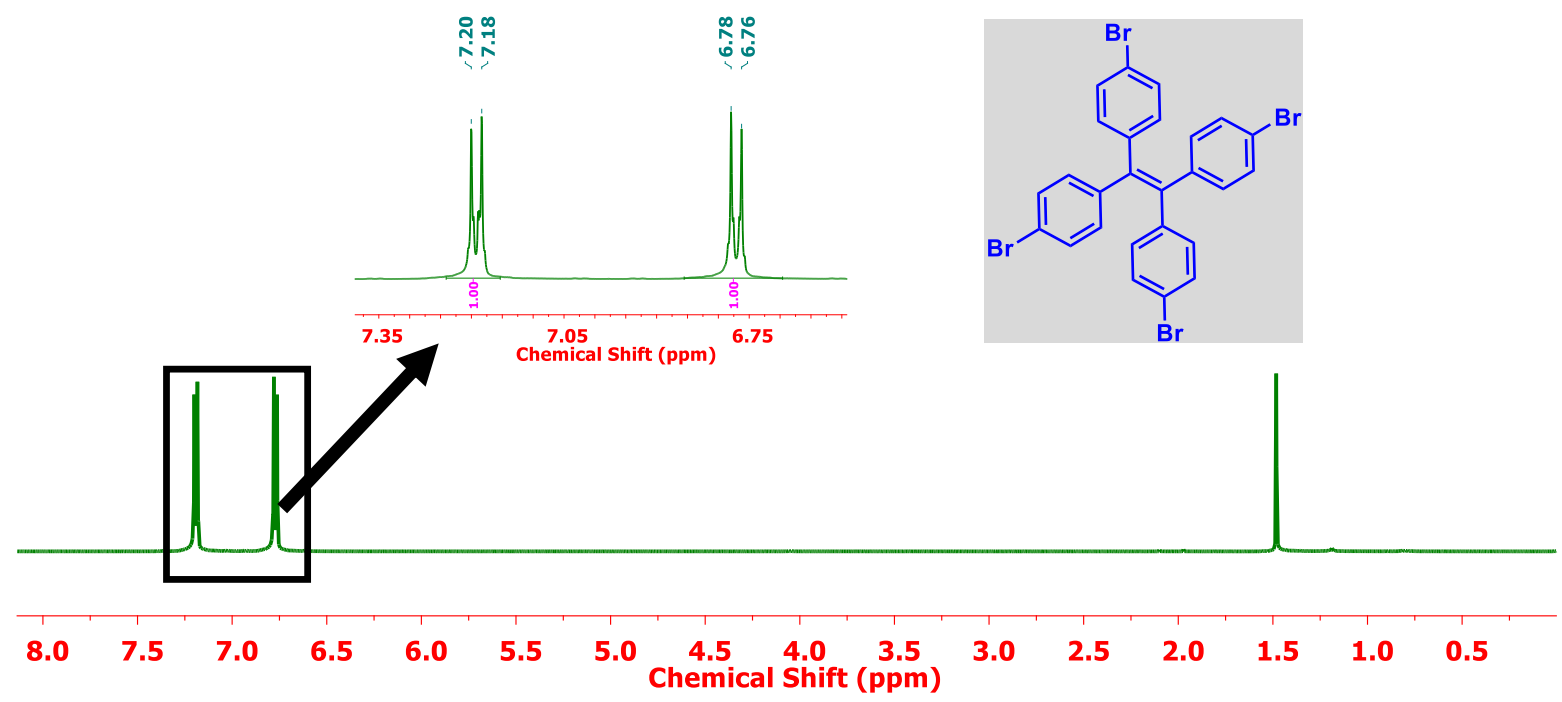

Figure S27: ${ }^{1} \mathrm{H}$ NMR of TPE-Br (b). 
Synthesis of TPE-Ester (c): TPE-Ester (diethyl (4-(1,2,2-tris(4(diethoxyphosphoryl)phenyl)vinyl)phenyl)phosphonate) was synthesised by following previously reported C-P coupling method ${ }^{3}$ using nickel(II) bromide. In the typical synthesis procedure, first $3 \mathrm{~g}$ of TPE-Br dissolved in $75 \mathrm{ml}$ 1,3-diisopropyl benzene was allowed to heat at $120{ }^{\circ} \mathrm{C}$ in an oil bath, then on cooling to $70{ }^{\circ} \mathrm{C}$ anhydrous $3 \mathrm{~g}$ nickel (II) bromide added with vigorous stirring. After that temperature gradually rose to $180{ }^{\circ} \mathrm{C}$ followed by very slow addition of $2.5 \mathrm{~mL}$ of triethyl phosphite (around $3 \mathrm{~h}$ ), the final mixture then allowed to heat for another $6 \mathrm{~h}$. On completion the volatile components and 1,3-disopropyl benzene were distilled off by vacuum distillation. The TPE-Ester was obtained from dark viscous residue on purification by column chromatography using Methanol/Dichloromethane. The product was characterised by ${ }^{1} \mathrm{HNMR}\left(400 \mathrm{MHz}, \mathrm{DMSO}_{6}, \mathrm{~d}_{6}, 298 \mathrm{~K}\right) \delta=7.15-7.18 \mathrm{ppm}(\mathrm{dd}, 8 \mathrm{H})$, 7.49-7.54 ppm (dd, 8H), 3.95-3.99 ppm (m, 16H), and 1.17-1.20 ppm (t, 24H) (Figure S28), ${ }^{13} \mathrm{CNMR}$ (Figure S29) and ${ }^{31} \mathrm{PNMR} \delta=17.23 \mathrm{ppm}$ (Figure S30)

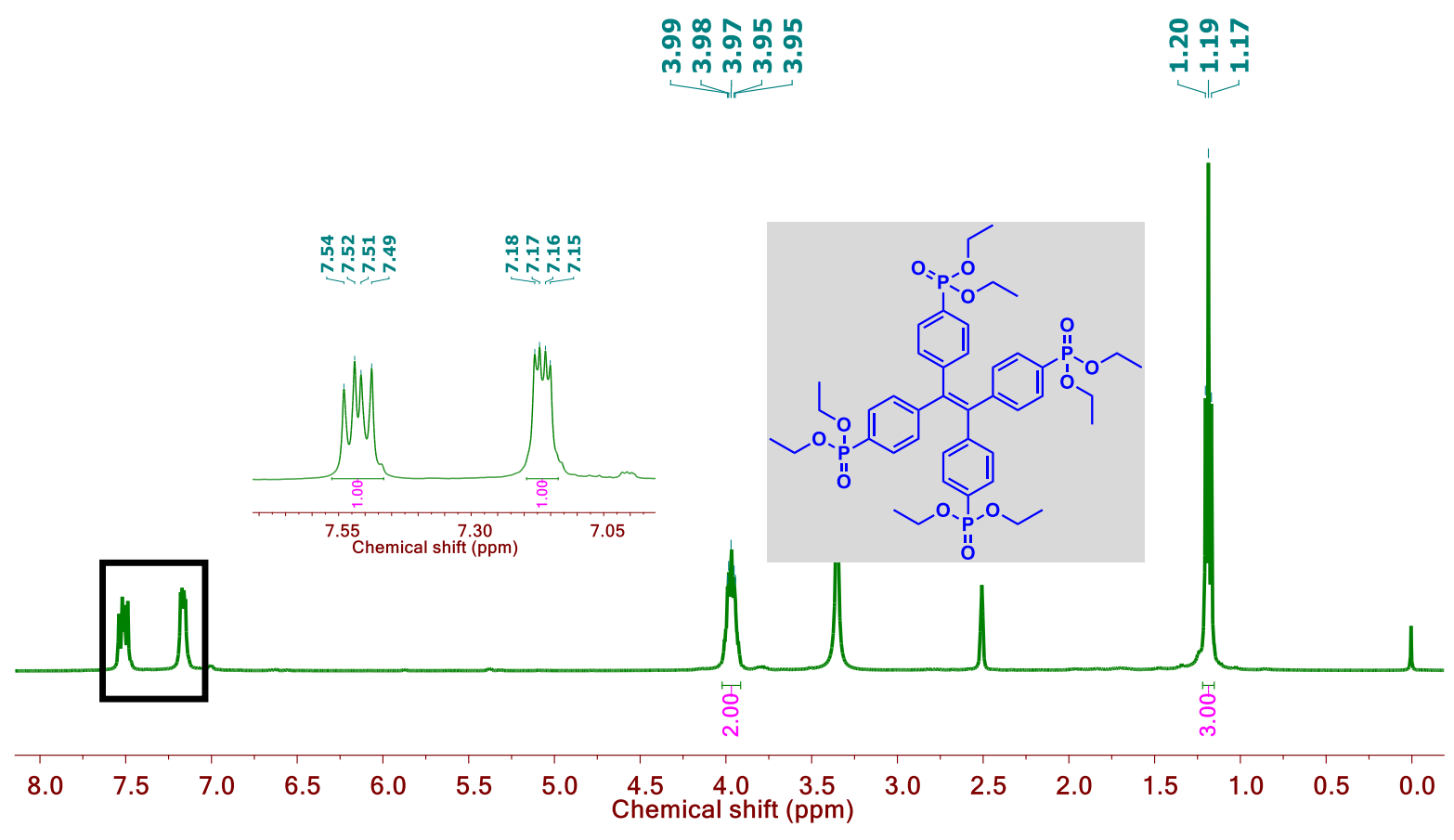

Figure S28: ${ }^{1} \mathrm{H}$ NMR of TPE-Ester (c). 
骨量糔

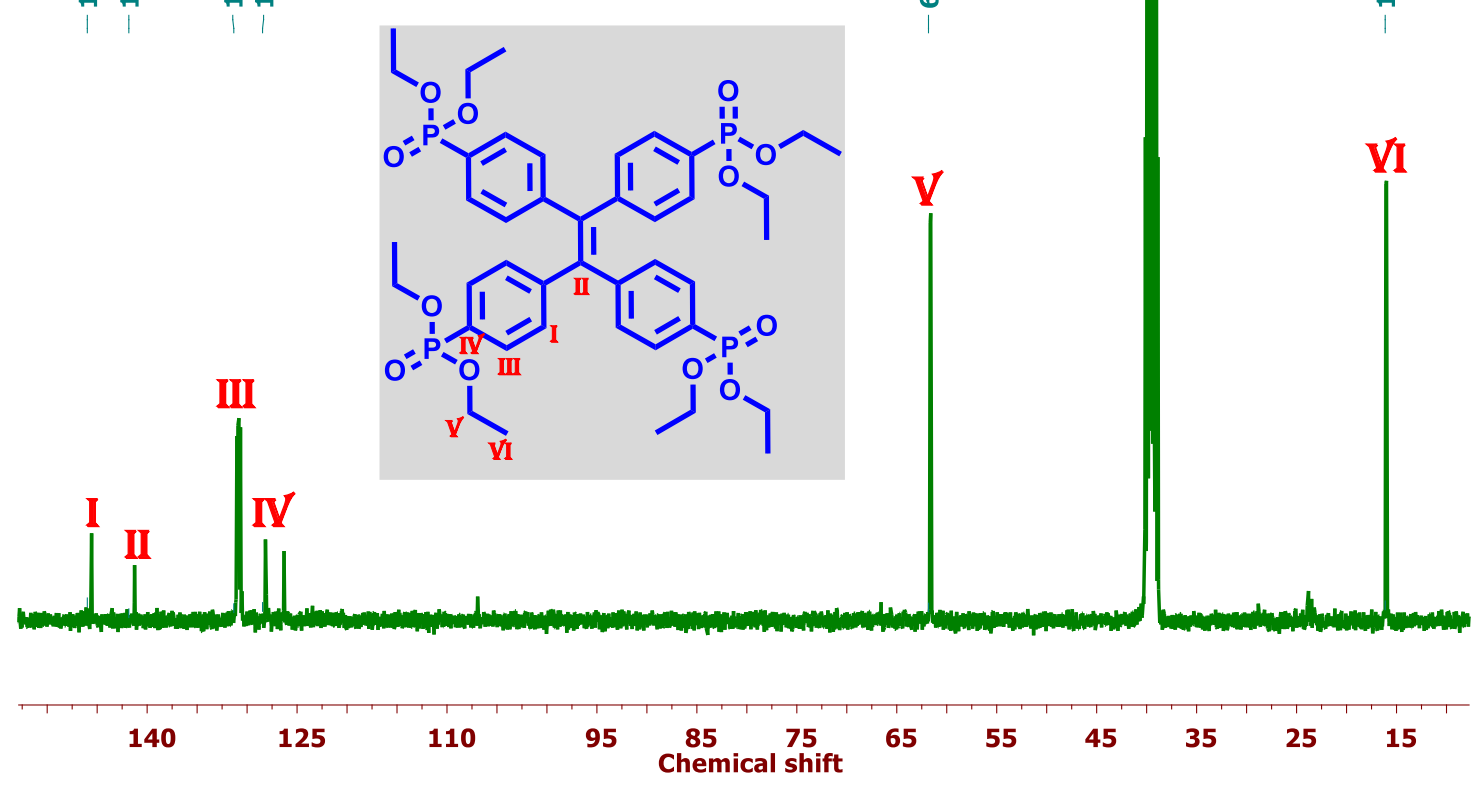

Figure S29: ${ }^{13} \mathrm{C}$ NMR of TPE-Ester (c).

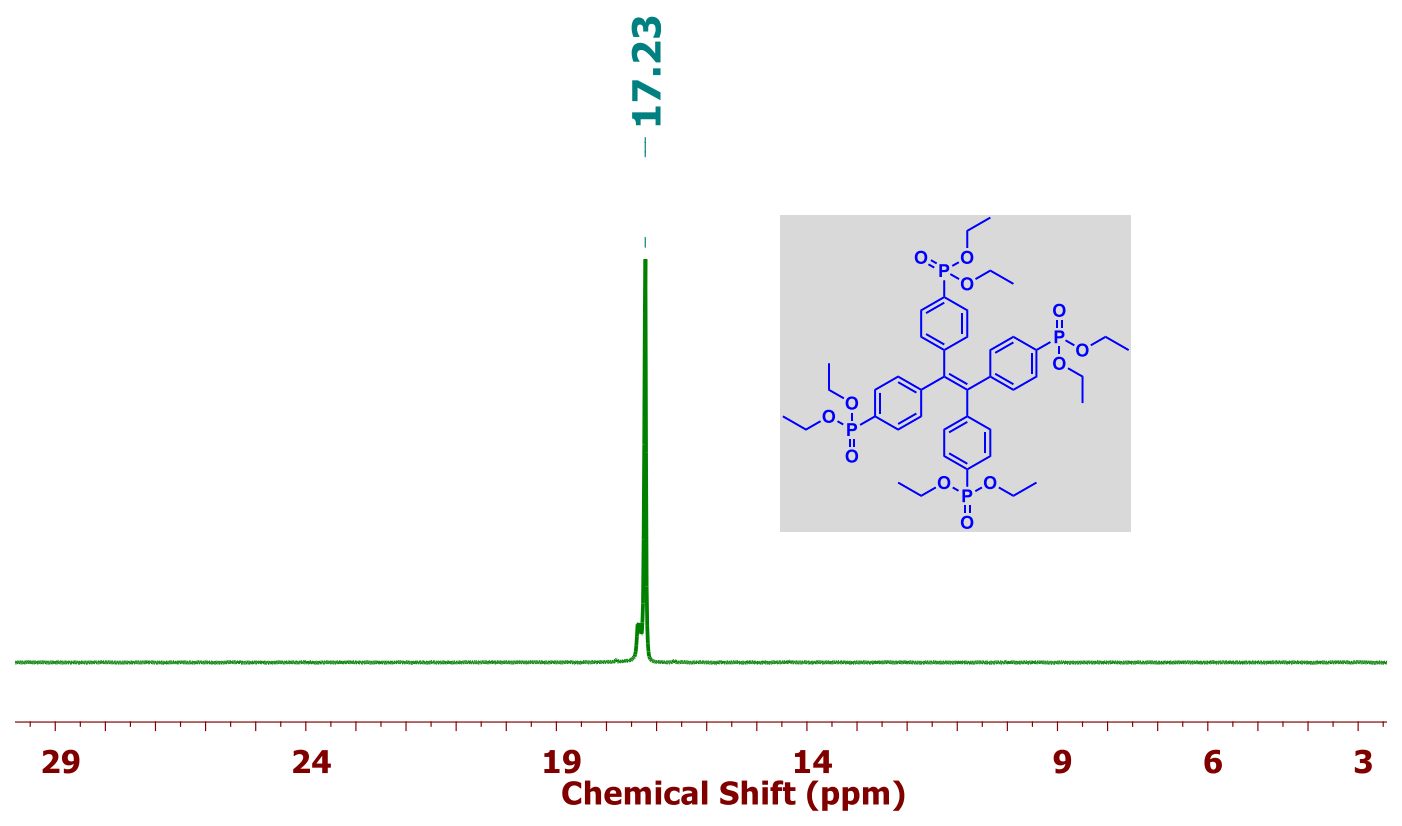

Figure S30: ${ }^{31} \mathrm{P}$ NMR of TPE-Ester (c).

Synthesis of HsL-Ligand (d) (TPE-Acid): The $\mathrm{H}_{8} \mathrm{~L}-\mathrm{Ligand}$ i.e. (4-(1,2,2-tris(4phosphonophenyl)vinyl)phenyl) phosphonic acid was prepared by hydrolysis of TPE-Ester. In the synthesis $4.5 \mathrm{~g}$ of produced ester was taken under acidic hydrolysis by $50 \mathrm{ml}$ concentrated $\mathrm{HCl}$ for $12 \mathrm{~h}$ at $100^{\circ} \mathrm{C}$. The hydrolysed solution was evaporated to dryness and the residue was dissolved in $15 \mathrm{ml}$ distilled water. The solution was decolorized by activated charcoal, and the filtrate was evaporated under reduced pressure to get $3.08 \mathrm{~g}$ of white solid TPE-Acid of $92 \%$ yield. The compound was characterized by ${ }^{1} \mathrm{H},{ }^{31} \mathrm{P}$ NMR. ${ }^{1} \mathrm{H}$ NMR (500 
$\mathrm{MHz}, \mathrm{D}_{2} \mathrm{O}+\mathrm{K}_{2} \mathrm{CO}_{3}$, at 298K)) $\delta=7.15-7.18 \mathrm{ppm}(\mathrm{dd}, 8 \mathrm{H})$; 7.44-7.49 ppm (dd, 8H) (Figure $\mathrm{S} 31),{ }^{31} \mathrm{P}$ NMR $\left(500 \mathrm{MHz}, \mathrm{D}_{2} \mathrm{O}+\mathrm{K}_{2} \mathrm{CO}_{3}\right.$, at 298K) $\delta=13.13 \mathrm{ppm}$ (Figure $\mathrm{S} 32$ ).

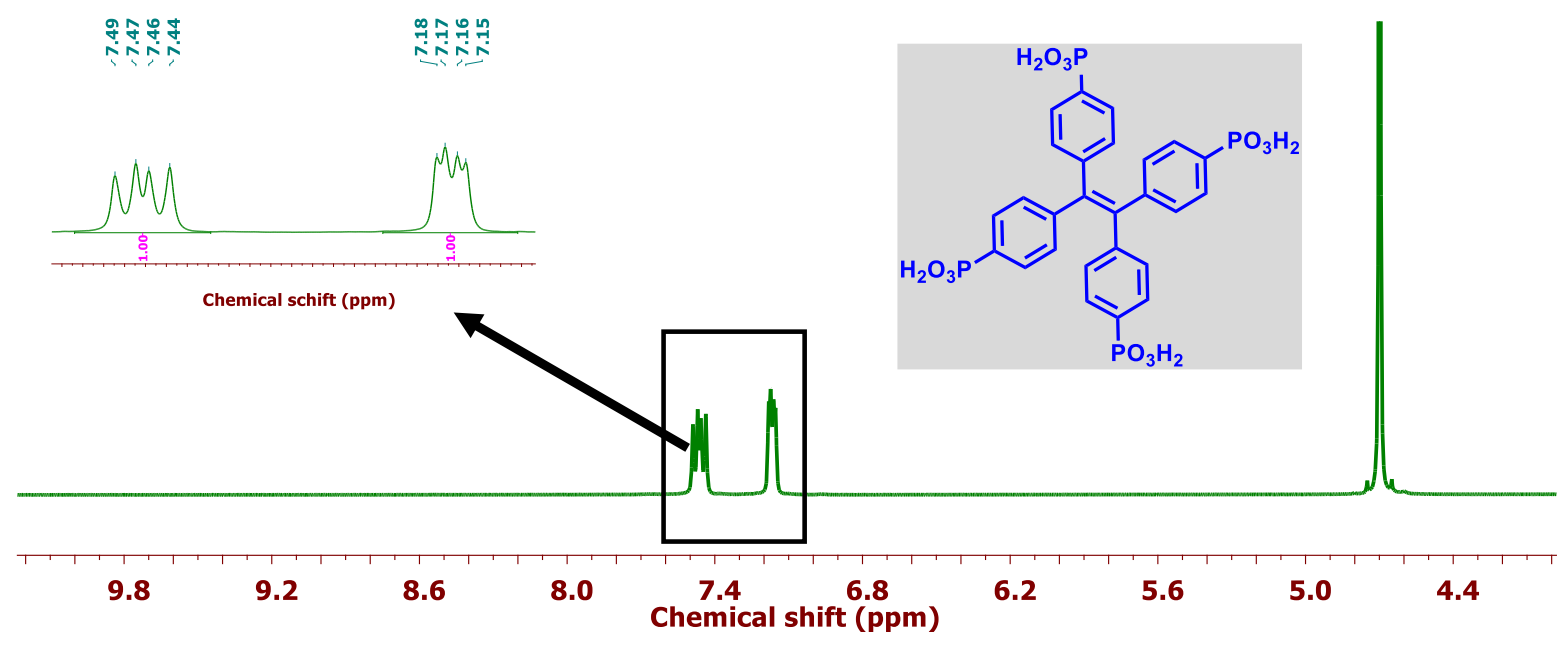

Figure S31: ${ }^{1} \mathrm{H}$ NMR of $\mathrm{H}_{8} \mathrm{~L}$ ligand (d).

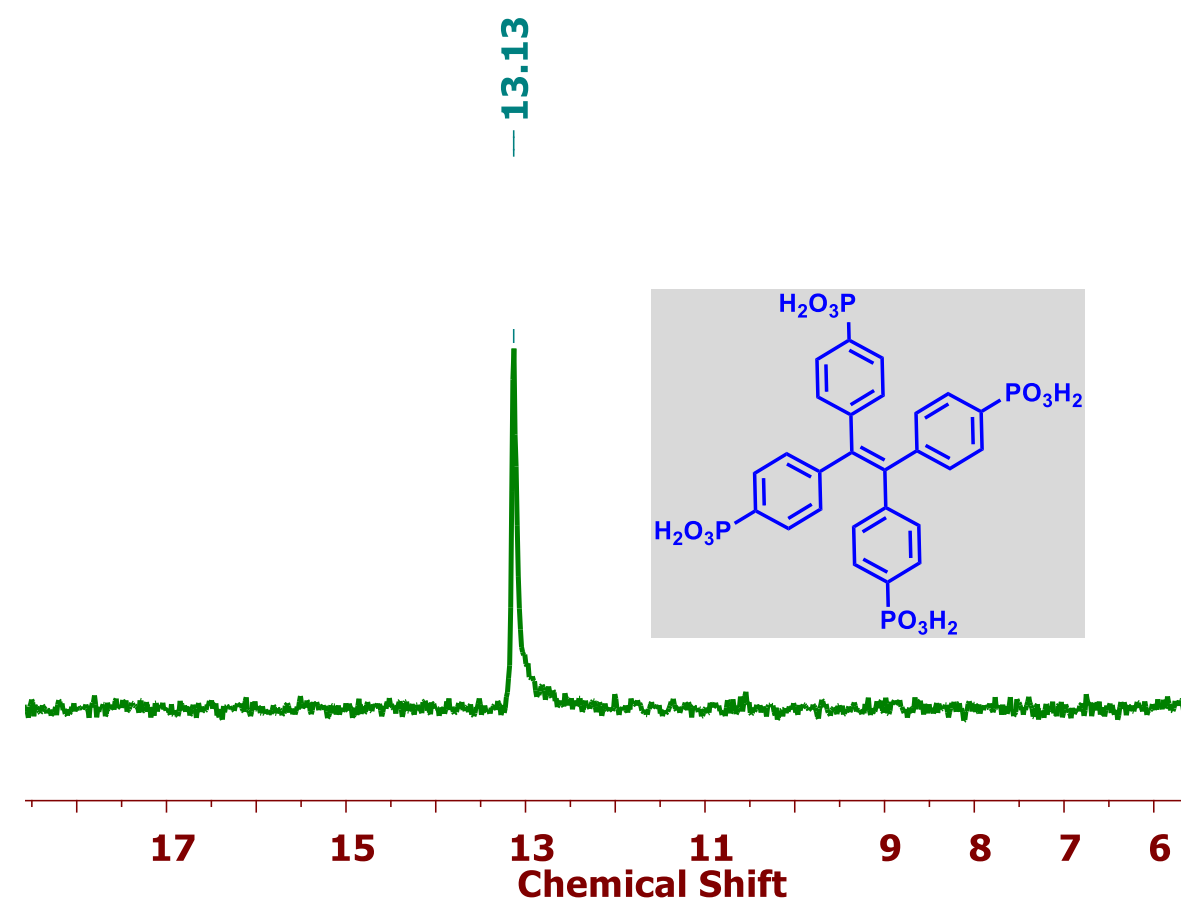

Figure S32: ${ }^{31} \mathrm{P}$ NMR of $\mathrm{H}_{8} \mathrm{~L}$ ligand (d)

\section{Crystal Structure Determination Technique.}

The diffraction data for $\mathrm{H}_{8} \mathrm{~L}-\mathrm{Co}-\mathrm{Crystal}$ collected in Bruker D8VENTURE Microfocus diffractometer equipped with PHOTON II Detector using Mo-K $\alpha$ radiation with a wavelength of $0.71073 \AA$ controlled by the APEX3 (v2017.3-0) software package. ${ }^{4}$ Single crystals were mounted with mineral oil coating under a $150 \mathrm{~K}$ nitrogen cold stream. The raw data were reduced and corrected for Lorentz and polarisation effects using the Bruker APEX II95/APEX III program suite and absorption corrections were performed using SADABS. 
The structures were solved by direct methods and refined by full-matrix least-squares using the SHELXTL software package. Space groups were assigned by analysis of metric symmetry and systematic absences (determined by XPREP) and were further checked by PLATON for additional symmetry. All the structures were solved by direct methods and were refined against all data in the reported $2 \theta$ ranges by full-matrix least-squares on F2 with the SHELXL program suite98 using the OLEX 299 interface. Hydrogen atoms are at idealized positions.

\section{TOF (Turn over Frequency) calculation}

TOF (Turn Over Frequency) number was estimated with the help of HER LSV plot (Fig. 3a). ${ }^{5}$ The total no of active centre into the metal organic framework was calculated from the single crystal diffraction data (CIF file). Number of active species $\left(\mathrm{Co}^{2+}\right)$ present into the $\mathrm{H}_{8} \mathrm{~L}$-Co-Crystal MOF, $\mathrm{m}=3.5 \times 10^{-8} \mathrm{~mol}$. Now, we calculate the per site turn-over frequency by using the following equation:

$\mathrm{TOF}=0.5 \times J \times A \times F \times m$

[0.5 in the above equation stands for the requisition of two electrons, which are required to produce one hydrogen molecule from two protons $\left(2 \mathrm{H}^{+}+2 \mathrm{e}^{-}=\mathrm{H}_{2}\right), \mathrm{J}=$ anodic current density), $\mathrm{A}=$ Surface area of the working electrode, $\mathrm{F}=$ faraday constant $\left(96485 \mathrm{C} \mathrm{mol}^{-1}\right), \mathrm{m}=$ mol amount of the active $\mathrm{Co}^{2+}$ ions].

TOF for $\mathrm{H}_{8} \mathrm{~L}-\mathrm{Co}-\mathrm{Crystal} \mathrm{MOF} 0.020 \mathrm{~s}-1$ @ $-0.28 \mathrm{~V}$ vs. RHE. 


\section{References}

(1) Qi, Q. K.; Liu, Y. F.; Fang, X. F.; Zhang, Y. M.; Chen, P.; Wang, Y.; Yang, B.; Xu, B.; Tian, W. J.; Zhang, S. X. A. AIE (AIEE) and mechanofluorochromic performances of TPEmethoxylates: effects of single molecular conformations. RSC Adv. 2013, 3, 7996-8002.

(2) Cirulli, M.; Kaur, A.; Lewis, J. E. M.; Zhang, Z.; Kitchen, J. A.; Goldup, S. M.; Roessler, M. M. Rotaxane-Based Transition Metal Complexes: Effect of the Mechanical Bond on Structure and Electronic Properties. J. Am. Chem. Soc. 2019, 141, 879-889.

(3) Pramanik, M.; Patra, A. K.; Bhaumik, A. Self-assembled titanium phosphonate nanomaterial having a mesoscopic void space and its optoelectronic application. Dalton Trans. 2013, 42, 5140-5149.

(4) Jana, M.; Majumder, A. C-S Bond Cleavage, Redox Reactions, and Dioxygen Activation by Nonheme Dicobalt(II) Complexes. Inorg. Chem. 2018, 57, 617-632.

(5) Cai, Z. S.; Shi, Y.; Bao, S. S.; Shen, Y.; Xia, X. H.; Zheng, L. M. Bioinspired Engineering of Cobalt-Phosphonate Nanosheets for Robust Hydrogen Evolution Reaction. ACS Catal. 2018, 8, 3895-3902. 